\title{
Innate immune properties of selected human neuropeptides against Moraxella catarrhalis and nontypeable Haemophilus influenzae
}

Daria Augustyniak ${ }^{1 *}$, Adam Jankowski ${ }^{1,2}$, Paweł Mackiewicz ${ }^{3}$, Agnieszka Skowyra', Jan Gutowicz ${ }^{4}$ and Zuzanna Drulis-Kawa'

\begin{abstract}
Background: Considerable evidence supports the concept of active communication between the nervous and immune systems. One class of such communicators are the neuropeptides (NPs). Recent reports have highlighted the antimicrobial activity of neuropeptides, placing them among the integral components of innate immune defense. This study examined the action of four human neuropeptides: calcitonin gene-related peptide (CGRP), neuropeptide $Y(N P Y)$, substance $P(S P)$ and somatostatin (SOM), which are accessible in the upper respiratory tract, against two human-specific respiratory pathogens. We studied: (i) neuropeptide-mediated direct antibacterial activity exerted against Moraxella catarrhalis and nontypeable Haemophilus influenzae, and (ii) indirect immunomodulatory role of these neuropeptides in the neutrophil-mediated phagocytosis of indicated pathogens.

Results: We found that 100 micromolar concentrations of CGRP, NPY, SP, and SOM effectively permeabilized bacterial membranes and showed (except SOM) bactericidal activity against both pathogens. SOM acted only bacteriostatically. However the killing efficacy was dependent on the bactericidal assay used. The rank order of killing NP effect was: NPY $\geq$ CGRP > SP >> SOM and correlated with their potency to permeabilize bacterial membranes. The killing and permeabilization activity of the analyzed NPs showed significant correlation with several physicochemical properties and amino acid composition of the neuropeptides. M. catarrhalis was more sensitive to neuropeptides than nontypeable $H$. influenzae.

The immunomodulatory bimodal effect of physiological concentrations of CGRP, NPY, and SP on the phagocytic function of human neutrophils against M. catarrhalis and $H$. influenzae was observed both in the ingestion (pathogen uptake) and reactive oxygen species generation stages. This effect was also dependent on the distinct type of pathogen recognition (opsonic versus nonopsonic).

Conclusions: The present results indicate that neuropeptides such as CGRP, NPY, and SP can effectively participate in the direct and indirect elimination of human-specific respiratory pathogens. Because the studied NPs show both direct and indirect modulating antimicrobial potency, they seem to be important molecules involved in the innate host defense against M. catarrhalis and nontypeable H. influenzae.
\end{abstract}

Keywords: Neuropeptide Y, Substance P, CGRP, Somatostatin, Killing, Permeabilization, Phagocytosis, Immunomodulation, Moraxella catarrhalis, Haemophilus influenzae

\footnotetext{
* Correspondence: daria.augustyniak@microb.uni.wroc.pl

'Department of Pathogen Biology and Immunology, Institute of Genetics and Microbiology, University of Wroclaw, Przybyszewskiego 63/77, 51-148 Wroclaw, Poland

Full list of author information is available at the end of the article
} 


\section{Background}

Central nervous system-mediated regulation of immunity occurs through systemic, regional and local routes. The peripheral nervous system provides a first line of defense at local sites through the release of neuropeptides (peptide neurotransmitters) from sensory nerves [1]. Sensory neuropeptides such as calcitonin generelated peptide (CGRP) and substance $\mathrm{P}(\mathrm{SP})$ as well as autonomic neuropeptide $\mathrm{Y}$ (NPY) and somatostatin (SOM) are widely distributed throughout the nervous system [2]. Numerous reports highlighted their role as bioactive molecules that exert immunomodulatory effects on innate and adaptive immune responses. The majority of the responses involve: (i) modulation of cytokine release by lymphocytes, monocytes/macrophages, and dendritic cells [3-5], (ii) regulation of lymphocyte and dendritic cells adhesion and activation [3,6], (iii) modulation of phagocytosis process $[7,8]$, and (iv) modulation of inflammatory response [9].

Unlike the lower respiratory tract, the upper human airways are richly innervated [10]. SP and CGRPcontaining nerves are present beneath and within the epithelium, around blood vessels and sub-mucosal glands and within the bronchial smooth-muscle layer [11]. Numerous nerves (with SP and CGRP) are located within the mucosal lining of the middle ear cavity [12]. Nasal mucosa is densely innervated by fibers containing NPY, SP, and CGRP $[13,14]$. The potential role of SP and CGRP in the pathogenesis of microbial-induced/associated airway diseases such as otitis media with effusion or chronic obstructive pulmonary disease has been postulated $[15,16]$. Airway lymphoid organs such as lymph nodes and tonsils receive both autonomic/sympathetic and sensory peptidergic innervations [10]. Interestingly, NPY, SP, and CGRP can be synthesized and released also from the immune cells such as lymphocytes or monocytes/macrophages [17-19]. Due to their cationic charge at neutral $\mathrm{pH}$, low molecular mass $(<10 \mathrm{kDa})$, and amphipathic properties, neuropeptides interact with the negatively charged surface of the microbial membrane resulting in membrane disruption and direct killing of the target cell [20]. Similarities between the NPs and the endogenous antimicrobial peptides led to the discovery of NPs antimicrobial activity directed against various bacteria and fungi [21-23], and place neuropeptides among factors that are capable of forming the local barriers of defense against pathogens.

Moraxella catarrhalis and nontypeable Haemophilus influenzae are important human-restricted respiratory tract pathogens that may occasionally cause invasive diseases $[24,25]$. They are both predominant etiological factors of otitis media and form biofilms in children with recurrent or chronic otitis media [26]. They both commonly colonize the lower airways of patients with chronic obstructive pulmonary disease, thus contributing to its pathogenesis $[27,28]$. Both species asymptomatically colonize the pharyngeal mucosa, a port of pathogen entry, and are present in nasopharyngeal secretions $[29,30]$. Colonization of host mucosal surfaces is the first and necessary step in the infectious process. Since the mucosal surfaces of the upper respiratory tract are richly innervated, both species are potentially exposed to the action of released neuropeptides.

This study was designed to elucidate two aspects of the antibacterial properties of neuropeptides CGRP, NPY, SP, and partly SOM: (i) the direct activity against Moraxella catarrhalis and nontypeable Haemophilus influenzae, (ii) the indirect action through the modulation of neutrophil phagocytosis by determination of bacterial uptake and respiratory burst response. We demonstrated temporary bactericidal activity of NPs as well as their opposite immunomodulatory action with reference to both studied critical phagocytic functions of neutrophil response against human-restricted respiratory pathogens.

\section{Methods}

\section{Neuropeptides, reagents, and media}

Calcitonin gene related peptide ( $\alpha$-CGRP), neuropeptide $\mathrm{Y}$ (NPY), substance P (SP), and somatostatin (SOM) were purchased from TOCRIS bioscences (Ellisville,

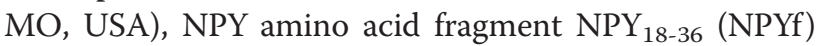
was bought from Sigma Chemicals (St Louis, MO, USA). All neuropeptides were dissolved in $0.01 \%(\mathrm{v} / \mathrm{v})$ acetic acid containing $0.1 \%$ human serum albumin (Sigma) and stored at $-20^{\circ} \mathrm{C}$ in working stock solutions at concentration of $10^{-3} \mathrm{M}$. Other reagents and supplies such as acridine orange, hemin, luminol, $\beta$-nicotinamide adenine dinucleotidem (NAD), $o$-nitrophenyl- $\beta$-D-galactopyranosid (ONPG), phorbol myristate acetate (PMA), polymyxin B sulfate salt, and trypan blue were from Sigma (Steinheim, Germany). Other reagents were: ficoll $1.115 \mathrm{~g} / \mathrm{ml}$ (AquaMed, Poland), FITC (Thermo Scientific, Rokford, USA), fMLF (Fluka, Switzerland), TSB - tripticasein soy broth (BIOCORP, Poland), BHI - brain heart infusion broth (Merck, Germany), HAEM chocolate plates (OXOID, Germany), agar-agar (Fluka, Spain), NaPB-1\% BHI, sodium phosphate buffer ( $\mathrm{pH}$ 7.4) containing $1 \% \mathrm{BHI}(\mathrm{w} / \mathrm{v})$; HBSS buffer with $\mathrm{Ca}^{++}$and $\mathrm{Mg}^{++}$(PAA, Austria), heat inactivated fetal bovine serum (HiFBS), GIBCO BRL.

\section{Bacterial strains}

M. catarrhalis ATCC 25238 and H. influenzae ATCC 49247 strains were used. Two clinical nasopharyngeal isolates of Moraxella catarrhalis (Mc5, Mc6) and nontypeable Haemophilus influenzae (NTHi3, NTHi6) were also included in some experiments. In ONPG assay, Escherichia coli $M L-35$ p a lactose permease-deficient 
strain with constitutive cytoplasmic $\beta$-galactosidase activity (from dr Timothy Starner) was used. The clinical isolates were obtained from Laboratory of Bacteriology of the Silesian Centre of Pediatrics in Wroclaw, Poland. The final identification of $M$. catarrhalis was made using a standardized commercial identification system API$\mathrm{NH}$ (Bio-Merieux, France). H. influenzae strains were identified by both $\mathrm{X}$ and $\mathrm{V}$ factor requirements, growth on chocolate agar but not on blood agar. The absence of bexA gene was confirmed by PCR capsular genotyping using $H$. influenzae type b as positive control [31]. NTHi strains were cultivated on HAEM chocolate agar plates or in BHI broth supplemented with hemin and NAD at final concentrations of $15 \mu \mathrm{g} / \mathrm{ml}$. M. catarrhalis strains were grown in BHI. E. coli ML-35p was maintained on TSB. All Mc and NTHi strains were grown at $37^{\circ} \mathrm{C}$ with $5 \% \mathrm{CO}_{2}$. The strains were stored in relevant medium containing $16 \%$ glycerol at $-70^{\circ} \mathrm{C}$.

\section{Antimicrobial assays}

To evaluate antimicrobial properties of purified neuropeptides two assays were used: (i) a radial diffusion assay [32] and (ii) a slightly modified liquid broth assay [33] referred to as the time kill assay from 0 to $1.5 \mathrm{~h}$.

For the radial diffusion assay a mid-log phase bacteria were diluted to the concentration of $\sim 1-2 \times 10^{6} \mathrm{CFU} / \mathrm{ml}$ in $10 \mathrm{ml}$ of melted and cooled to $42^{\circ} \mathrm{C}, 1 \%$ agarose $(\mathrm{w} / \mathrm{v}$, molecular biology grade) in $10 \mathrm{mM}$ sodium phosphate containing 1/100 dilution of full strength BHI and $0.02 \%(\mathrm{v} / \mathrm{v})$ Tween 20 (Sigma). After vigorous mixing, the bacteria in the agarose were poured onto Petri plate forming underlayer in which $3 \mathrm{~mm}$ diameter sterile wells were cut. The wells were filled with serially diluted neuropeptides $(5 \mu \mathrm{l})$ at concentrations ranging from $10^{-6} \mathrm{M}$ to $10^{-3} \mathrm{M}$ and plates were incubated for $3 \mathrm{~h}$ at $37^{\circ} \mathrm{C}$ to allow peptide diffusion. The plates were then overlaid with $10 \mathrm{ml}$ of the buffered $1 \%$ agarose containing $6 \% \mathrm{BHI}(\mathrm{w} / \mathrm{v})$ and allowed to harden. After overnight incubation at $37^{\circ} \mathrm{C}$ the diameters of inhibition zones were measured and antimicrobial activities of NPs expressed as minimal inhibitory concentrations (MIC) were evaluated. The MIC value was determined as the $\mathrm{x}$-axis intercept obtained from the relationship between the diameter of radial diffusion zones versus NP concentration. Resistance was defined for MIC greater than $500 \mu \mathrm{g} / \mathrm{ml}$ [22]. Polymyxin B was used as a positive control.

For the time kill assay from 0 to $1.5 \mathrm{~h}$, overnight cultures of Mc and NTHi were inoculated into new medium and incubated under the relevant conditions until early log-phase $\left(\mathrm{OD}_{600}=0.25-0.3\right)$. The bacteria were diluted in $10 \mathrm{mM}$ sodium phosphate buffer, $\mathrm{NaPB},(\mathrm{pH} 7.4)$ containing $1 \%(\mathrm{w} / \mathrm{v}) \mathrm{BHI}$ to obtain $\sim 2 \times 10^{6} \mathrm{CFU} / \mathrm{ml}$. The bacterial suspensions were incubated in the presence of $10 \mu \mathrm{M}$ and $100 \mu \mathrm{M}$ concentrations of SP, CGRP, NPY, and
SOM in a final volume of $100 \mu \mathrm{l}$ NAPB-1\% BHI, for $0,0.5$ and $1.5 \mathrm{~h}$ at $37^{\circ} \mathrm{C}$ in water bath. After each time of incubation the suspensions were 10-fold serially diluted with $10 \mathrm{mM} \mathrm{NaPB}-1 \% \mathrm{BHI}$ and $20 \mu \mathrm{l}$ aliquots were plated in triplicate on BHI (M. catarrhalis) or HAEM (H. influen$z a e)$ agar plates. The plates were incubated overnight at $37^{\circ} \mathrm{C}$ in $5 \% \mathrm{CO}_{2}$ conditions. Simultaneously, the incubation of bacteria in the presence of an appropriate diluent was included for positive control of bacterial growth. The colony counts and CFU/ml were calculated next day. The bactericidal activity of neuropeptides was expressed as survival ratios determined as the numbers of CFU after neuropeptide incubation divided by the numbers of CFU estimated from a control plate (time 0). All antimicrobial assays were performed at least two times in triplicate.

\section{Membrane permeability assay}

To measure the activity of neuropeptides in permeabilization of bacterial membrane, the ONPG-mediated $\beta$-galactosidase microplate assay was used. Permeabilization was measured using E. coli ML-35 with constitutive cytoplasmic $\beta$-galactosidase activity as previously described [34,35]. Briefly, $18 \mathrm{~h} \mathrm{E}$. coli ML-35p in TSB was recultivated in TSB until mid-log phase $\left(\mathrm{OD}_{600}=0.5\right)$. Flasks were put on ice for $20 \mathrm{~min}$, and $2 \mathrm{ml}$ of bacterial suspensions were transferred to Eppendorf tubes, washed twice with $10 \mathrm{mM}$ sodium phosphate $\mathrm{NaPB}(\mathrm{pH}$ 7.4) and suspended in $\mathrm{NaPB}$ to $\mathrm{OD}_{600}=0.5$. Bacterial suspensions were diluted in $\mathrm{NaPB}$ to obtain $10^{6} \mathrm{CFU} / \mathrm{ml}$ and incubated on the flat bottomed 96-well plate (NUNC, Denmark) with various concentrations $\left(10^{-6}-10^{-4} \mathrm{M}\right)$ of CGRP, SP, SOM, NPY, and NPY ${ }_{18-36}$ diluted in NaPB with $3 \mathrm{mM}$ ONPG as $\beta$-galactosidase substrate in the final volume of $150 \mu \mathrm{l}$. Microplates were incubated at $37^{\circ} \mathrm{C}$ for $1.5 \mathrm{~h}$ and optical densities were measured every 15 minutes at $\lambda=405 \mathrm{~nm}$ (spectrophotometer Opsys MR Dynex Technologist). All the assays were performed in triplicate. Two positive controls were used: polymyxin B at the final concentration of $1 \mu \mathrm{g} / \mathrm{ml}$ as an established model of peptide permeabilizing action, and $20 \%$ chloroform (v/v). Chloroform, as an indicator of extensive permeabilization (arbitrarily defined as maximal) which led to the maximal OD increase, was used in order to quantitatively calculate and compare the permeabilizing strength of studied NPs. We estimated their molar concentration defined as the inducible dose $\left(\mathrm{ID}_{50}\right)$ that caused $50 \%$ increase in OD calculated with reference to the chloroform-inducible maximum, 45 min after the beginning of measurement. The molar concentration of NP that caused such increase was extrapolated from a linear portion of NP titration curve. Negative controls constituted bacteria incubated with $\mathrm{NaPB}$ and ONPG but without neuropeptides. 


\section{Isolation of PMNs}

Polymorphonuclear leukocytes (PMNs) from healthy young adult volunteers were isolated from venous blood samples anticoagulated with Lithium-heparin $(7.5 \mathrm{ml})$ by ficoll (Aqua-Med, Poland) density gradient centrifugation (2000 rpm/30 min), followed by hypotonic lysis of erythrocytes with a lysing buffer $\left(0.83 \% \mathrm{NH}_{4} \mathrm{Cl}, 0.1 \%\right.$ $\mathrm{KHCO}_{3}$, EDTA, pH 7.4). After two washes (1400 rpm/ $10 \mathrm{~min}$ ) in PBS, PMNs were resuspended to the final concentration of $10^{7}$ cells $/ \mathrm{ml}$ in phagocytic buffer: HBSS with $\mathrm{Ca}^{++}$and $\mathrm{Mg}^{++}$supplemented with $1 \%$ HiFBS. The purity of granulocyte suspensions was checked using $15 \mu \mathrm{g} / \mathrm{ml}$ of acridine orange. The cell suspensions containing at least $95 \%$ of PMNs were used for the phagocytosis assays described below. Cell viability was determined to be $>97 \%$ by trypan blue staining. Isolated PMNs were kept for $30 \mathrm{~min}$ at $37^{\circ} \mathrm{C}$ and $5 \% \mathrm{CO}_{2}$ until used.

The study was approved by the Research Ethics Committee of the Medical University of Wroclaw and informed consent was obtained from all volunteers.

\section{Phagocytosis assay}

i. Labeling of bacteria with fluorescein isothiocyanate (FITC): FITC-labeled bacteria were prepared as described previously [36]. Briefly, bacteria $M$. catarrhalis ATCC 25238 and NTHi ATCC 49247 from overnight cultures were harvested, suspended into PBS and adjusted to an $A_{600}$ of $1(\mathrm{OD}=1)$ corresponding to $\sim 2 \times 10^{9} \mathrm{CFU} / \mathrm{ml}$. Heat-killed bacterial suspensions at $\mathrm{OD}=1$ were labeled with $1 \mathrm{mg} / \mathrm{ml}$ of FITC at $0.05 \mathrm{M}$ carbonate/bicarbonate buffer (pH 9.5), for $30 \mathrm{~min}$ at $37^{\circ} \mathrm{C}$ with gentle mixing in the dark. FITC-conjugated bacteria were washed 3 times by centrifugation with cold carbonate/bicarbonate buffer in order to remove the excess of FITC, and finally resuspended in HBSS- $\mathrm{Ca}^{++} \mathrm{Mg}^{++}$at $1 / 10$ of original volume.

ii. Opsonization: FITC-labeled bacteria in HBSS$\mathrm{Ca}^{++} \mathrm{Mg}^{++}$were opsonized with post-immunized $10 \%$ heat-inactivated pooled murine antisera for $30 \mathrm{~min}$ at $37^{\circ} \mathrm{C}$ with rotation, followed by washing with PBS. Antisera from mice immunized with whole bacteria (Mc or NTHi) had whole cell ELISA titers of specific IgG antibodies, which were $>1$ : 10,000.

iii. Bacterial uptake: $50 \mu \mathrm{l}$ of PMNs $\left(10^{7}\right.$ cells $\left./ \mathrm{ml}\right)$ in phagocytic buffer was mixed with $10 \mu \mathrm{l}$ of FITClabeled targets supplemented with 5\% HiFBS and $10^{-8} \mathrm{M}$ concentration of NPs in a final volume of $100 \mu \mathrm{l}$ and incubated at $37^{\circ} \mathrm{C}$ for $30 \mathrm{~min}$ with gentle agitation on rotary shaker $(100 \mathrm{rpm})$. Phagocytosis was terminated by placing the samples briefly on ice. Parallel controls were kept on ice to block endocytic uptake of the targets. Cells were treated with $0.2 \mathrm{mg} / \mathrm{ml}$ of trypan blue solution to quench extracellular fluorescence [37]. Each assay was performed at least three times in duplicate. The concentration of NPs indicated as the most potent within the range $10^{-12}$ to $10^{-8} \mathrm{M}$, was chosen on the basis of preliminary experiments.

iv. Flow cytometric analysis: Fluorescence of FITClabeled bacteria ingested by granulocytes (FITCpositive granulocytes) was measured by FACS Calibur (Becton Dickinson). Before analysis the samples were diluted 1:5 in cold HBSS- $\mathrm{Ca}^{++} \mathrm{Mg}^{++}$. PMNs were distinguished from other leukocytes by gating on forward- and sideward-scatter signals, then this population was analyzed for green fluorescence in the FL1 channel. 15,000 events were measured to assess the percentage of phagocytizing neutrophils and the mean fluorescence intensity (MFI) of PMNs. Data were obtained using Becton Dickinson software and further analysis was performed using WinMDI 2.8 software. Data were expressed as the percentage of phagocytosis in reference to control values $(100 \%=$ phagocytosis without NPs) or as the MFI of PMN.

\section{Detection of ROS formation by chemiluminescence}

Reactive oxygen species (ROS) formation by PMNs was measured using luminol-dependent chemiluminescence assay (CL) in white flat-bottom 96-well microplates (NUNC, Denmark). The reaction mixture of total volume $200 \mu \mathrm{l}$ in each well contained: $100 \mu \mathrm{l}$ of PMN suspension in $\mathrm{HBSS}-\mathrm{Ca}^{++} \mathrm{Mg}^{++}\left(10^{5}\right.$ cells/well $), 40 \mu \mathrm{l}$ of luminol (50 $\mu \mathrm{M} /$ well), $40 \mu \mathrm{l}$ of fMLP $(0.2 \mu \mathrm{M} /$ well $), 20 \mu \mathrm{l}$ of particular NP (in the range $10^{-12}-10^{-8} \mathrm{M} /$ well). In other experiments, the respiratory burst was triggered by phagocytosis of $40 \mu \mathrm{l}$ heat killed $\left(56^{\circ} \mathrm{C} / 30 \mathrm{~min}\right) \mathrm{M}$. catarrhalis ATCC 25238 or $H$. influenzae ATCC 49247 at concentration of $1 / 2$ of $\mathrm{OD}_{600}=1$ or $\mathrm{OD}_{600}=1$, respectively. In these experiments, only the most potent NPs concentration $\left(10^{-8} \mathrm{M}\right)$ was used. The PMA stimulus at $0.1 \mu \mathrm{M}$ final concentration was used as positive control of the relevant oxidative stress. The CL kinetics was measured at constant $37^{\circ} \mathrm{C}$ temperature using luminometer (Microlumat, LB96P, Berthold) and recorded as relative light units (RLU). Measuring conditions for fMLP were: interval (46 s), run time (up to $30 \mathrm{~min}$ ). The conditions for bacterial and PMA stimulation were: interval (83 s), run time (up to $60 \mathrm{~min}$ ). The maximal value of CL response curve was expressed as peak height $\left(\mathrm{PH}_{\mathrm{CL}}\right)$ for fMLP stimulant. In other cases the area under chemiluminescence curve $\left(\mathrm{AUC}_{\mathrm{CL}}\right)$ was calculated [38]. Each sample was run in triplicate and the values were averaged. Relative CL was calculated as: mean $\mathrm{AUC}_{\mathrm{CL} \text { of sample }} /$ mean $\mathrm{AUC}_{\mathrm{CL} \text { of control }} \times$ $100 \%$. Results were expressed as mean \pm SD. After 
measurements the viability of PMNs was confirmed to be $>93 \%$ using trypan blue exclusion.

\section{Relationship between the direct antibacterial activity of peptides and their physicochemical characteristics}

The relationship of neuropepeptide activities with their different physicochemical properties and amino acid composition were correlated using Spearman's rank coefficient. The antibacterial properties of the analyzed neuropeptides were expressed as survival ratios after $1.5 \mathrm{~h}$ of bacterial exposure whereas permeability properties were measured by peptide concentration (expressed in $\mu \mathrm{M}$ ) that caused $50 \%$ increase $\left(\mathrm{ID}_{50}\right)$ in the membrane permeability (measured by OD) after 45 minutes from the beginning of the experiment. In the analyses we also included the antibacterial properties (expressed as MIC in $\mu \mathrm{M})$ of neuropeptides/peptides published by other scientists $[21,23]$. The data from experiments performed on different bacteria but for the same or overlapping set of peptides were min-max normalized to be included in one meta-analysis. Ten physicochemical properties deduced from sequences of the peptides were considered. Isoelectric point was calculated based on the standard iterative algorithm used in ExPASy Proteomics Server [39]. Appropriate amino acid indices downloaded from ExPASy Proteomics Server were applied to calculate polarity [40], hydropathicity [41], transmembrane tendency [42], and conformational parameter for $\alpha$-helix and $\beta$-sheet [43]. Maximum hydrophobic moment was calculated as implemented in hmoment from EMBOSS package [44]. The NPs composition of amino acids classified to four different physicochemical groups: nonpolar (A, C, F, G, I, L, M, P, V, W), polar uncharged (N, $\mathrm{Q}, \mathrm{S}, \mathrm{T}, \mathrm{Y})$, basic $(\mathrm{H}, \mathrm{K}, \mathrm{R})$, and $\operatorname{acidic}(\mathrm{D}, \mathrm{E})$ was analyzed.

\section{Statistical analysis}

Normality and homogeneity of variance assumptions were checked using Shapiro-Wilk's and Levenea's test, respectively. For multiple comparisons, data were analyzed using one-factor analyses of variance (ANOVA) and were followed by post hoc effects (Tuckey's test or Duncan's test). Spearman's rank correlation coefficients were used for the relationship assessment. Results were expressed as means \pm SEM of the $n$ independent experiments performed in triplicate and containing cells from separate donors. For the comparison of ROS generation or phagocytic uptake by bacteria-stimulated PMNs in response to neuropeptides, the data were normalized to a baseline control value (without NPs) of $100 \%$. A $P$ value $<0.05$ was used to assess the significance of all statistical analyses. All the analyses were performed with STATISTICA 9 software.

\section{Results}

Rank order of permeabilizing potency of neuropeptides In order to determine the potency of CGRP, NPY, its truncated fragment $\mathrm{NPY}_{18-36}$, SOM and SP on permeability of the gram-negative bacteria membrane, a model microorganism, E. coli ML-35p and $\beta$-galactosidase assay were used. The time-dependent increase in absorbance at $405 \mathrm{~nm}$ in this assay is the result of permeability of both the inner and outer bacterial membranes, confirmed by the intracellular influx of the extracellular dye ONPG that is hydrolyzed by constitutively expressed $\beta$ galactosidase [34]. In each set of experiments, polymyxin $B$ was used as the first positive control and the established model of peptide permeabilizing action. The second positive control employed chloroform which caused an extensive bacterial membrane permeabilization, and led to the maximal OD increase.

Tested neuropeptides displayed an activity in bacterial membrane permeability in a time- and dose-dependent manner (Figure 1). An examination of the neuropeptideinduced ONPG influx, as a function of time indicates that the shapes of permeability profiles were similar whereas time courses of the maximal permeability for all tested NPs used at highest $(100 \mu \mathrm{M})$ concentrations were slightly different. CGRP induced the maximal OD increase at $50 \mathrm{~min}, \mathrm{NPY}$ and $\mathrm{NPY}_{18-36}$ at $75 \mathrm{~min}$, whereas SP and SOM at $90 \mathrm{~min}$ from the beginning of the reaction, followed by a gradual decrease in OD over time (not shown). Concentrations of $10 \mu \mathrm{M}$ exerted permeabilizing potency for all tested neuropeptides except SOM, and induced a maximal OD increase at $\sim 90 \mathrm{~min}$ of ONPG influx (only for NPY $\mathrm{N}_{18-36}$ it was $~ 75 \mathrm{~min}$ ). To quantitatively calculate the permeabilizing potency of NPs, we estimated their molar concentration defined as the inducible dose $\left(\mathrm{ID}_{50}\right)$ that caused $50 \%$ increase in OD calculated in reference to the chloroform-inducible maximum at $45 \mathrm{~min}$. The molar concentration of NPs calculated for different times and raw permeability values led to the same final conclusion. The neuropeptide concentrations needed for 50\% ONPG influx are presented in Table 1 . Their permeability potency against $E$. coli ML-35p increased in the following order: $\mathrm{SOM}<<\mathrm{SP}<\mathrm{NPY} \leq \mathrm{CGRP}<\mathrm{NPY}_{18-36}$. These findings demonstrate that the four studied NPs efficiently permeabilized bacterial membranes of the model microorganism $E$. coli ML-35p with $\mathrm{NPY}_{18-36}$ being the most effective and SOM the least.

\section{Killing efficacy of $M$. catarrhalis and $H$. influenzae by CGRP, NPY, SP, and SOM}

The permeabilizing potency of peptide may sometimes not correlate with its lethal effect. Moreover, there are some discrepancies concerning the direct antibacterial action of neuropeptides used in this study [22,23], and 

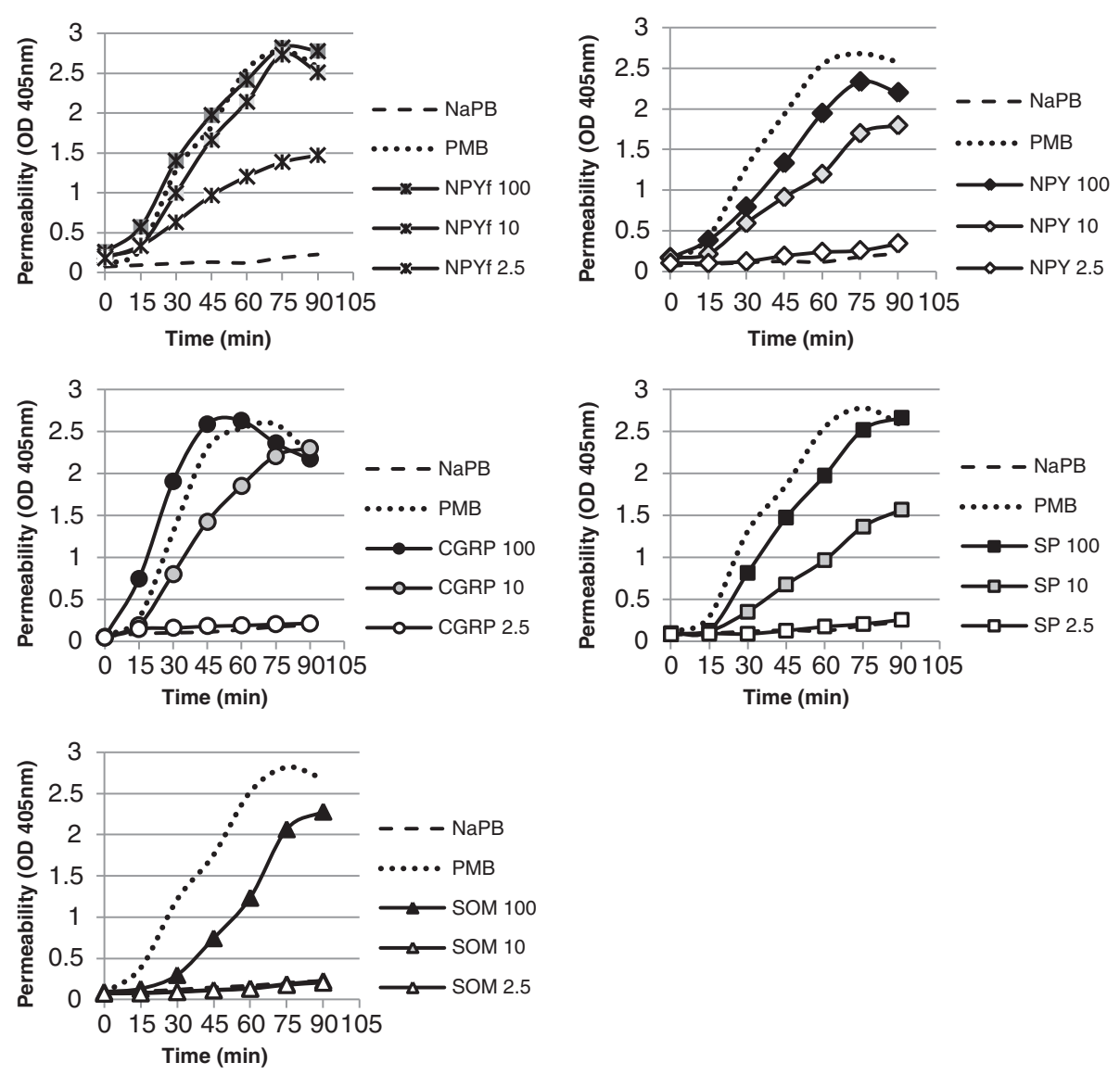

Figure 1 Permeabilizing potency of neuropeptides against E.coli ML-35p, determined by $\beta$-galactosidase assay with ONPG as its substrate. Bacteria at $10^{6} \mathrm{CFU} / \mathrm{ml}$ were incubated at $37^{\circ} \mathrm{C}$ for $90 \mathrm{~min}$ in the presence of the indicated micromolar concentrations of neuropeptides: neuropeptide $Y(N P Y)$, fragment of neuropeptide $Y\left(N P Y f=N P Y{ }_{18-36}\right)$, calcitonin gene related peptide (CGRP), substance P (SP), and somatostatin (SOM). In negative controls, bacteria incubated in neuropeptide-free NAPB containing 1/100 of TSB showed no net hydrolysis of ONPG. Polymyxin B (PMB) at $1 \mu \mathrm{g} / \mathrm{ml}$ was included as a positive control. The representative curves of at least three independent experiments are presented.

their activity against clinical respiratory pathogens has not been elucidated so far. Thus in the next step we compared the killing efficacy of effective permeabilizing neuropeptide doses (10 and $\left.10^{2} \mu \mathrm{M}\right)$ against isolates of $M$. catarrhalis and $H$. influenzae using two methods: (i) a radial diffusion assay and (ii) a time kill assay from

Table 1 Parameter defining NP-induced intracellular influx of ONPG into E.coli ML-35p

\begin{tabular}{ll}
\hline Neuropeptide & ${ }^{*} \mathbf{D}_{\mathbf{5 0}}[\boldsymbol{\mu} \mathbf{M}]$ \\
\hline NPY ${ }_{18-36}$ & 2.0 \\
NPY & 19.3 \\
CGRP & 11.5 \\
SP & 29.2 \\
SOM & 104.1 \\
\hline
\end{tabular}

${ }^{*} \mathrm{I}_{50}$ (inducible dose) - dose of NP that caused $50 \%$ increase in OD calculated in the reference to the chloroform-inducible maximum at $45 \mathrm{~min}$ of experiment. The values carry a standard error of approximately.
0 to $1.5 \mathrm{~h}$. In the radial diffusion assay CGRP, NPY, $\mathrm{NPY}_{18-36}$, SP, and SOM were tested against $M$. catarrhalis ATCC 25238, $H$. influenzae ATCC 49247, and four clinical respiratory isolates of $M$. catarrhalis (Mc5, Mc6) and non-typeable $H$. influenzae (NTHi3, NTHi6). In this assay, within used NPs ranges from $1 \mu \mathrm{M}$ to $10^{2} \mu \mathrm{M}$, all tested $M$. catarrhalis and $H$. influenzae strains were susceptible only to the truncated form of neuropeptide $\mathrm{Y}$ $\left(\mathrm{NPY}_{18-36}\right) . M$. catarrhalis strains were generally two/ three-fold more susceptible (MICs from 8 to $12.5 \mu \mathrm{M}$ ) than $H$. influenzae (MICs from 25 to $40 \mu \mathrm{M}$ ). In order to test if higher doses of NPs (apart from NPY $\mathrm{N}_{18-36}$ ) can be bactericidal, two additional concentrations, $5 \times 10^{2} \mu \mathrm{M}$ and $10^{3} \mu \mathrm{M}$ were used. Weak inhibition zones were observed for four NPs at indicated concentrations. CGRP, NPY, SP, and SOM exhibited no antimicrobial activity in the radial diffusion assay as their MICs for all 6 isolates of both $M$. catarrhalis and $H$. influenzae were higher than 
$117 \mu \mathrm{M}$ (NPY), $132 \mu \mathrm{M}$ (CGRP) and $300 \mu \mathrm{M}$ (SP and SOM) which corresponded to $500 \mu \mathrm{g} / \mathrm{ml}$, defined as the cut off for antimicrobial neuropeptide activity [22,23]. The similar results were obtained for additional tested isolates of both species (data not shown). In control experiments all tested $M$. catarrhalis and $H$. influenzae isolates showed susceptibility to polymyxin B within a range from $0.39 \mu \mathrm{g} / \mathrm{ml}$ to $3.12 \mu \mathrm{g} / \mathrm{ml}$ and from $1.56 \mu \mathrm{g} /$ $\mathrm{ml}$ to $6.25 \mu \mathrm{g} / \mathrm{ml}$, respectively.

In contrast to the radial diffusion assay, three studied neuropeptides (except SOM) exerted killing effect in the time kill assay from 0 to $1.5 \mathrm{~h}$. As illustrated on survival plots (Figure 2). M. catarrhalis strains were in general more susceptible to the tested neuropeptides than $H$. influenzae. Use of $100 \mu \mathrm{M}$ concentration of CGRP, NPY, and SP against $M$. catarrhalis resulted in killing of both tested Mc strains that occurred in a time-dependent manner. NPY killed more than 95\% of bacterial cells of both strains after $0.5 \mathrm{~h}$ and nearly $99 \%$ of them after $1.5 \mathrm{~h}$. CGRP was less potent than NPY in killing $M$. catarrhalis. In its presence $\sim 40 \%$ of Mc5 and more than $20 \%$ of Mc6 cells were killed after $0.5 \mathrm{~h}$ incubation, and respectively nearly $90 \%$ and more than $60 \%$ were killed after $1.5 \mathrm{~h}$. The lethal activity of SP against Mc5 and Mc6 strains was similar. SP was bactericidal for $43 \%$ of Mc5 cells and $52 \%$ of Mc 6 cells after $1.5 \mathrm{~h}$, whereas after $0.5 \mathrm{~h}$ incubation nearly $100 \%$ of both cultures survived. Interestingly $100 \mu \mathrm{M}$ SOM elicited bacteriostatic activity for both Mc strains. There was no M. catarrhalis growth inhibition when all NPs were used at $10 \mu \mathrm{M}$ (data not shown). All neuropeptides displayed a similar pattern of killing activity against $H$. influenzae strains NTHi3 and NTHi6. Similarly to $M$. catarrhalis, no growth inhibition was observed for any NPs used at a $10 \mu \mathrm{M}$ concentration. The evaluation of NTHi survival revealed that in the presence of the most potent $100 \mu \mathrm{M}$ NPY $\sim 75 \%$ of NTHi3 and NTHi6 were killed after $1.5 \mathrm{~h}$ incubation whereas after $0.5 \mathrm{~h}$ NPY led to the death of up to $20 \%$ of the bacteria. $100 \mu \mathrm{M}$ SP was able to reduce the bacterial viability of both strains by at least $30 \%$ after $1.5 \mathrm{~h}$. CGRP killed $\sim 30 \%$ of NTHi6 after $0.5 \mathrm{~h}$ and $\sim 60 \%$ after $1.5 \mathrm{~h}$, whereas for NTHi3 its effect was bacteriostatic. The incubation of Mc and NTHi strains without neuropeptides (controls) showed an approximate 1.5-fold increase of bacterial growth after $1.5 \mathrm{~h}$ of incubation. Extension of incubation of Mc and NTHi strains in the presence of
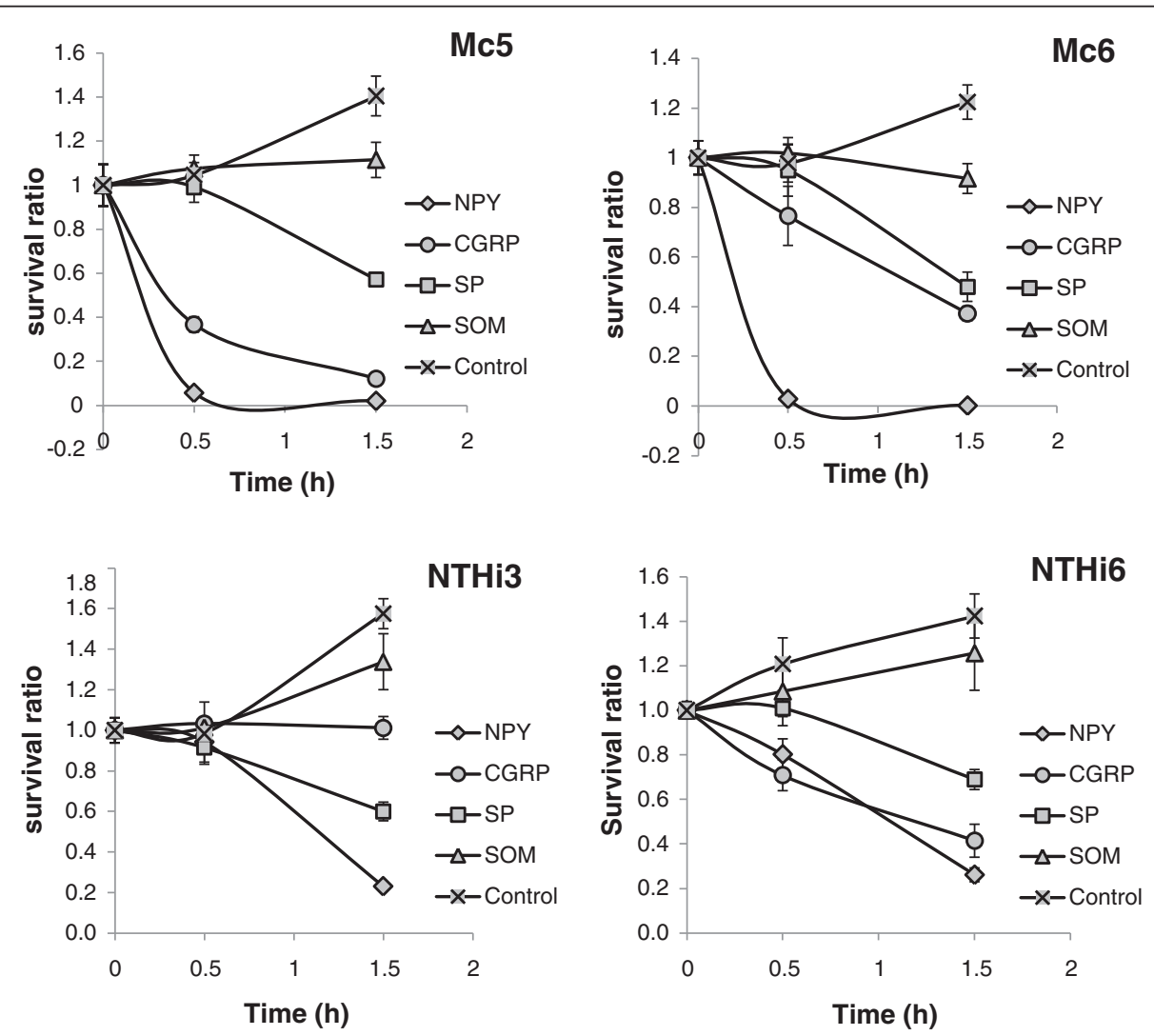

Figure 2 Neuropeptide-mediated killing of $\boldsymbol{M}$. catarrhalis (Mc) and nontypeable $\boldsymbol{H}$. influenzae (NTHi). Bacteria at $\sim 2 \times 10^{6} \mathrm{CFU} / \mathrm{ml}$ were incubated at $\mathrm{NaPB}-1 \% \mathrm{BHI}(\mathrm{V} / \mathrm{W})$ containing $100 \mu \mathrm{M}$ concentration of NPY, CGRP, SP, and SOM for 0.5 and $1.5 \mathrm{~h}$. Serially diluted aliquotes were plated on $\mathrm{BHI}$ agar. The data are expressed as mean survival ratios \pm SEM from two independent experiments performed in triplicate. 
NPs up to the $3 \mathrm{~h}$ resulted in the abolishment of NPmediated bactericidal activity and in a gradual increase in bacterial growth (data not shown), indicating that NPs are efficient in killing mucosal pathogens within a short time period.

Thus, apart from bacteriostatic SOM, $100 \mu \mathrm{M}$ concentration of CGRP, NPY, and SP are bactericidal against clinical isolates of $M$. catarrhalis and $H$. influenzae. NPmediated killing occurred within 1.5 hours of exposure in a time-dependent manner. These data also indicate that the rank order of bactericidal activity of $100 \mu \mathrm{M}$ NPs was similar to that of the permeabilizing potency with NPY $>$ CGRP $\geq$ SP $>>$ SOM. Overall, these data indicate that CGRP, NPY, SP and SOM at micromolar concentrations have the capacity, respectively to kill high numbers of mucosal pathogens and inhibit their growth within short time period.

Relationships between the direct antibacterial activities of peptides and their physicochemical characteristics

Some relationships between antimicrobial effect of the endogenous peptides and their amino acid composition or physicochemical properties have been reported [45]. Most of these peptides form cationic amphipathic secondary structures, typically $\alpha$-helices and $\beta$-sheets with high hydrophobicity. In order to assess these relationships quantitatively for the analyzed neuropeptides, we correlated their permeability effectiveness and killing efficacy expressed as survival ratios with their different physicochemical properties and amino acid composition. We also compared the results with data for other peptide sets with experimentally determined antimicrobial activity gathered from papers $[21,23]$. Spearman's rank correlation coefficients between antibacterial activity of peptides and their physicochemical characterization for particular experiments were presented in Figure 3, whereas coefficients shown in Table 2 were calculated for min-max normalized data from several experiments performed on different bacteria and for the same or overlapping set of peptides.

The correlations obtained for the peptides studied in this paper were very similar, irrespective of the antimicrobial measure: effectiveness of permeabilization or bacterial killing (Figure 3). The antimicrobial activity increased significantly with length, molecular mass, polarity, hydrophobic moment, and content of acidic residues in the peptides whereas it decreased with their tendency to form transmembrane domains, content of non-polar amino acid residues and hydropathicity (Table 1). However, the antibacterial potency for the sets of peptides taken from [21] increased significantly with isoelectric point, charge, tendency to form transmembrane domains and $\alpha$-helices or $\beta$-sheet structures whereas decreased with polarity (Table 1). According to data by [23], peptides with larger charge, hydropathicity and tendency to form $\beta$-sheet structures showed higher activity against bacteria (Table 1).

\section{NP-mediated modulation of bacterial uptake by PMNs}

NP-induced phagocytosis may be triggered as a result of both non-specific and specific ligand-receptor interaction and may depend on the nature of the engulfed pathogen $[8,46]$. We investigated whether SP, NPY, and CGRP exert a modulating role in the uptake of mucosal pathogens by freshly isolated human granulocytes, and whether such modulation involves a distinct type of pathogen recognition (opsonic versus nonopsonic phagocytosis). As expected, precoating $M$. catarrhalis with $10 \%$ antiserum significantly enhanced the phagocytic capacity of PMNs (MFI 1411.2 $\pm 111.8(\mathrm{SEM}) ; \mathrm{n}=6$ ) in comparison to nonopsonic conditions (MFI $289.7 \pm 51.5 ; \mathrm{n}=6$; $p<0.004)$ and respectively nearly $97 \% \pm 0.49 \%$ versus $83 \% \pm 3.9 \%$ of FITC-positive granulocytes $(\mathrm{n}=6 ; p<0.02)$ were detected by FACs. Uptake of $H$. influenzae revealed a similar 4-fold increase under opsonic versus non-opsonic conditions (Figure 4A). The observed opsonic phagocytic potency of PMNs against both mucosal pathogens was next markedly improved in the presence of NPs (Figure 4B). As shown in Figure 4C the enhancement of serum opsonized M. catarrhalis or H. influenzae uptake was from $\sim 18 \%$ to $\sim 50 \%$ and from $\sim 11 \%$ to nearly $42 \%$, respectively, depending on the tested NP with evident potency of NPY $\geq$ CGRP $>$ SP. These results suggest that the stimulatory effects of NPY, CGRP, and SP on PMN uptake seem to be additive to the opsonin action. Figure $4 \mathrm{~B}$ and $\mathrm{C}$ demonstrate that, when nonopsonized $M$. catarrhalis or $H$. influenzae cells were ingested by PMNs, their uptake in the presence of neuropeptides remained unchanged or was slightly diminished (up to $15 \%$ inhibition) compared to non-stimulated positive control indicating no effect or slightly inhibitory action. Moreover, as expected, the differences in magnitude of the modulating properties of NPs were also dependent on the PMN source thereby reflecting the actual physiologic conditions and vital responsiveness of PMNs from various donors. We postulate from this finding a stimulating action of the NPs, which depends on the phagocytic recognition of the studied mucosal pathogens and is connected with opsonin presence.

\section{NP-mediated modulation of ROS metabolism by PMNs}

The luminol-dependent chemiluminescence (CL) response was used to measure the bactericidal activity of PMNs. Since the kinetics of the CL response triggered by fMLF and phagocytosable bacteria or PMA, including both the magnitude and the temporal pattern were quite different, we used in calculations $\mathrm{PH}_{\mathrm{CL}}$ and $\mathrm{AUC}_{\mathrm{CL}}$, respectively. In preliminary experiments, in order to choose the most effective modulating doses of neuropeptides, 


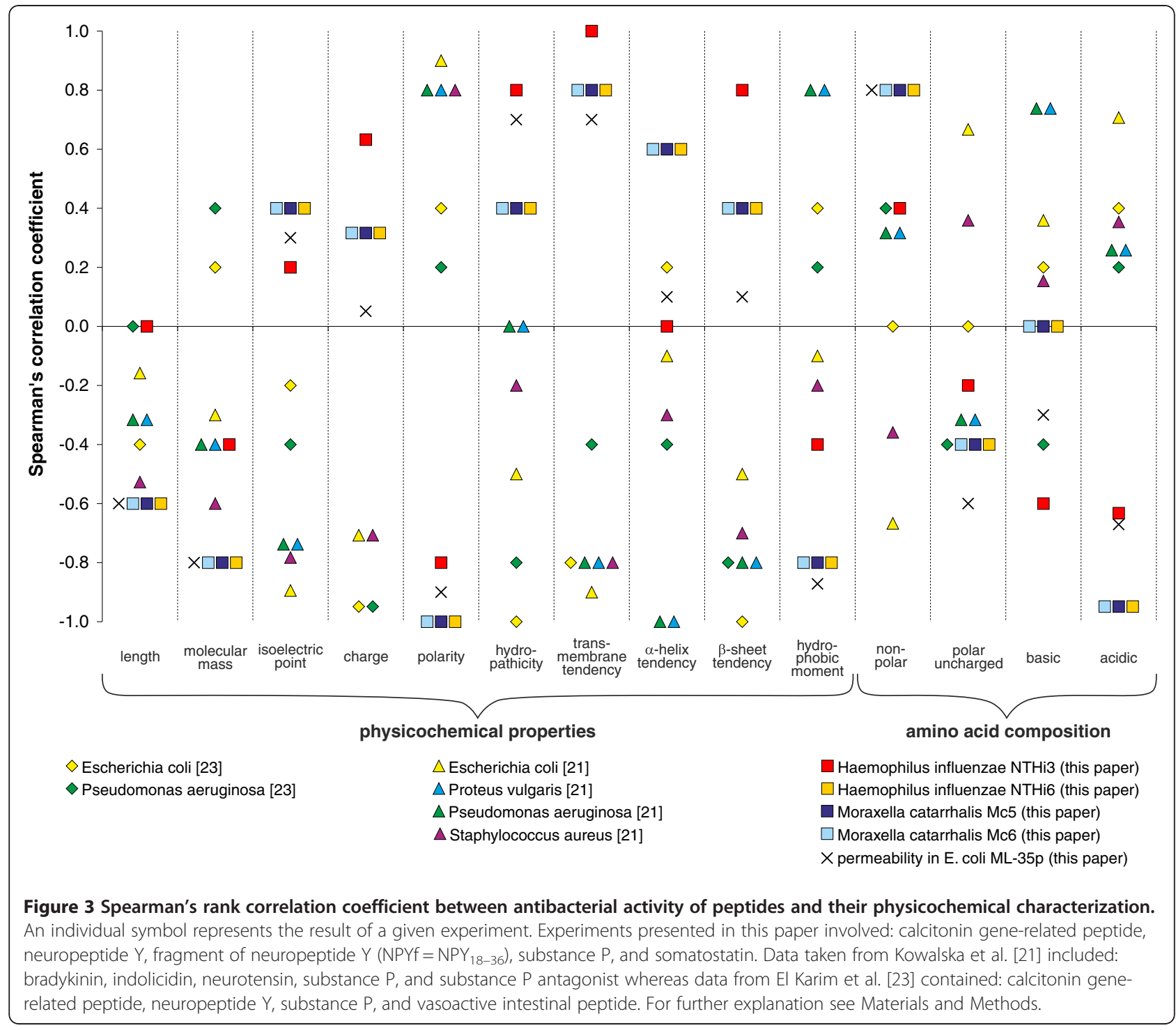

fMLF stimulation was used. This stimulation generated a sharp maximum, which was observed within $\sim 5 \mathrm{~min}$ of ROS response, followed by a subsequent decline to the baseline. The significant stimulatory effects of various physiological doses of neuropeptides $\left(10^{-12} \mathrm{M}-10^{-8} \mathrm{M}\right)$ on the luminol-dependent CL responses of PMNs activated by fMLF are shown in Table 3 . The amplification of ROS release, with maximal effect observed at $\sim 5 \mathrm{~min}$ of fMLF exposure, was more potent under lower NP concentrations with the rank order of CGRP $>$ SP $>$ NPY. Neuropeptides CGRP, SP, and NPY alone did not activate a respiratory burst of PMNs. To evaluate whether the NPmediated intensification of respiratory burst by PMNs was more relevant to PMN physiology, the respiratory burst activity was determined following stimulation by $M$. catarrhalis ATCC 25238 and NTHI ATCC 49247. Additionally, we explored the question if such modulation involves distinct types of pathogen recognition (opsonic versus nonopsonic). Incubation of human PMNs with opsonized as well as nonopsonized $M$. catarrhalis or nontypeable $H$. influenzae resulted in substantial ROS generation, peaking between 35 and $40 \mathrm{~min}$, followed by a gradual decrease. As shown in Figure 5A, for a representative experiment, the opsonization with $10 \%$ heat inactivated antiserum increased both the rate and the total production of ROS, which for both studied bacteria, was approximately 2-fold higher comparing to nonopsonic stimulation. In this case, $\log _{10}$ of mean $\mathrm{AUC}_{\mathrm{CL}} \pm$ SEM for opsonized versus nonopsonized $M$. catarrhalis and $H$. influenzae was $5.71 \pm 4.67$ versus $5.39 \pm 4.47$ and $4.99 \pm 3.62$ versus $4.69 \pm 3.3$, respectively. As shown in Figure 5B, only CGRP used at $10^{-8} \mathrm{M}$ significantly intensified the respiratory burst of PMNs triggered by phagocytosable $M$. catarrhalis in the absence of serum, thus confirming partly the results 


\begin{tabular}{|c|c|c|c|}
\hline \multirow{2}{*}{$\begin{array}{l}\text { Physicochemical } \\
\text { characteristics }\end{array}$} & \multicolumn{3}{|c|}{ Peptide set analysed in: } \\
\hline & this paper & [21] & [23] \\
\hline length & $-0.44(0.044)$ & $-0.33(0.174)$ & $-0.25(0.555)$ \\
\hline molecular mass & $-0.69(0.000)$ & $-0.42(0.085)$ & $0.27(0.515)$ \\
\hline isoelectric point & $0.31(0.164)$ & $-0.78(0.000)$ & $-0.27(0.515)$ \\
\hline charge & $0.32(0.160)$ & $-0.48(0.043)$ & $-0.94(0.001)$ \\
\hline polarity & $-0.91(0.000)$ & $0.79(0.000)$ & $0.32(0.438)$ \\
\hline hydropathicity & $0.57(0.006)$ & $-0.14(0.572)$ & $-0.91(0.002)$ \\
\hline $\begin{array}{l}\text { transmembrane } \\
\text { tendency }\end{array}$ & $0.82(0.000)$ & $-0.79(0.000)$ & $-0.64(0.086)$ \\
\hline a-helix tendency & $0.31(0.170)$ & $-0.58(0.012)$ & $-0.02(0.954)$ \\
\hline$\beta$-sheet tendency & $0.41(0.063)$ & $-0.66(0.003)$ & $-0.91(0.002)$ \\
\hline $\begin{array}{l}\text { maximum hydrophobic } \\
\text { moment }\end{array}$ & $-0.72(0.000)$ & $0.26(0.306)$ & $0.32(0.438)$ \\
\hline non-polar residues [\%] & $0.70(0.000)$ & $-0.13(0.600)$ & $0.15(0.726)$ \\
\hline polar residues [\%] & $-0.41(0.063)$ & $0.13(0.600)$ & $-0.15(0.726)$ \\
\hline basic residues [\%] & $-0.23(0.316)$ & $0.44(0.065)$ & $-0.02(0.954)$ \\
\hline acidic residues [\%] & $-0.79(0.000)$ & $0.38(0.123)$ & $0.32(0.438)$ \\
\hline
\end{tabular}

The data from experiments performed on different bacteria but for the same or overlapping set of peptides' set were min-max normalized and included in one analysis. For further explanation see Materials and Methods. Results significant with $p$-value $<0.05$ were shown in bold.

obtained with soluble fMLF. There were, however, some differences in the sensitivity of the PMNs responses to the individual bacterial stimulant as well as interindividual variation in ROS generation. ROS production by PMNs to $M$. catarrhalis was generally more sensitive to NPs than equivalent response to NTHi. Data obtained for $M$. catarrhalis (Figure $5 \mathrm{~B}$ ) show that the mean $\mathrm{AUC}_{\mathrm{CL}}$ of $\mathrm{PMNs}$ stimulated with these bacteria was increased in the presence of SP by $14.2 \pm 3.4 \%$ (range: $10.3-20.1 \%, \mathrm{n}=6$ ), CGRP by $40.5 \pm 22.3 \%$ (range: $22.7-75.7 \%, \mathrm{n}=6$ ) and NPY by $7.5 \pm 4.0 \%$ (range: $3.5-12.8 \%, n=5$ ). The stimulatory effect of NPs in the presence of NTHi was relatively weaker. The mean relative CL increase elicited (4 donors) was: SP $8.2 \pm 5.4$ (range: $3.2-17.0 \%$ ), CGRP $10.4 \pm 9.3$ (range: $0.0-25.0 \%$ ) and NPY $2.2 \pm 9.3$ (range: $0.0-12.7 \%$ ). The observed stimulating effect of NPs was not preserved for both opsonized bacteria (Figure 5B). Under these conditions the relative amounts of ROS were usually diminished up to $15 \%$ below the level of control ROS production. It indicated an inhibitory rather than stimulatory action of CGRP and inhibitory action of NPY during the response to $M$. catarrhalis. The similar modulating tendency of NPs, although not significant, was shown for NTHi. PMNs without bacteria or those stimulated only with NPs did not release significant amounts of ROS. The analysis of PMA-induced CL in PMNs was included in each experiment as an internal standard of relevant PMN activation. A stimulation with PMA always generated the strongest and slightly biphasic response with usually two separate maxima ( 10 min, and $\sim 25 \mathrm{~min})$ which gradually decreased. The $\log _{10}$ of mean $\mathrm{AUC}_{\mathrm{CL}} \pm$ SEM calculated from 0 to $60 \mathrm{~min}$ for that soluble and stabile stimulant was $6.05 \pm 4.32$ (not shown data from five independent experiments done in triplicate, using PMNs from 5 blood donors). Taken together, the presented data suggest that CGRP and less NPY at physiological concentrations are modulators of the respiratory burst of PMNs in response to $M$. catarrhalis, whereas in the case of nontypeable $H$. influenzae these effects are notable for CGRP and SP.

\section{Discussion}

Moraxella catarhalis and nontypeable Haemophilus influenzae are human-restricted mucosal pathogens that may potentially be exposed to the action of locally released neuropeptides. The importance of neuropeptides as the initial innate defenders seems to be associated with their direct (bactericidal) and indirect (modulatory) activity. The findings of the study demonstrate the complex antibacterial activity of neuropeptides CGRP, NPY, SP, and partially also SOM, against $M$. catarrhalis and nontypeable $H$. influenzae. Initially, we evaluated the direct antibacterial activity of neuropeptides, and found, using model E. coli ML-35p strain, that CGRP, NPY, NPY ${ }_{18-36}$ and SP at concentrations of $100 \mu \mathrm{M}$ and $10 \mu \mathrm{M}$, and SOM at $100 \mu \mathrm{M}$ are effective permeabilizers. The activity of NPs was time and dose-dependent with the following potency order of permeabilization: $\mathrm{NPY}_{18-36}>\mathrm{CGRP} \geq$ NPY $>$ SP $>>$ SOM. This effect was probably the result of neuropeptide-mediated sequential permeabilization of the outer and inner membrane of gram-negative bacteria since such mechanism is dedicated to other endogenous antimicrobial peptides $[34,47]$.

The permeabilizing activity of peptides sometimes may not correlate with their killing properties [48]. Thus, our next experiments aimed at determining the nature of antibacterial activity of effective permeabilizing NP doses, more specifically, whether they are bactericidal or bacteriostatic? We found that $100 \mu \mathrm{M}$ CGRP, NPY, and SP exerted bactericidal and time-dependent impact on the metabolically active $M$. catarrhalis and $H$. influenzae within $1.5 \mathrm{~h}$. This indicated, at micromolar concentrations, their temporary capacity to kill high numbers of respiratory pathogens. The action of SOM proved, at the same time, to be bacteriostatic. The following potency order of bactericidal action was established: NPY $>$ CGRP $\geq$ SP $>>$ SOM. In general, neuropeptides start to kill $M$. catarrhalis within $0.5 \mathrm{~h}$, whereas the killing of $H$. influenzae is slightly delayed in time. Threshold concentration of NPs being similar, this would indicate that 


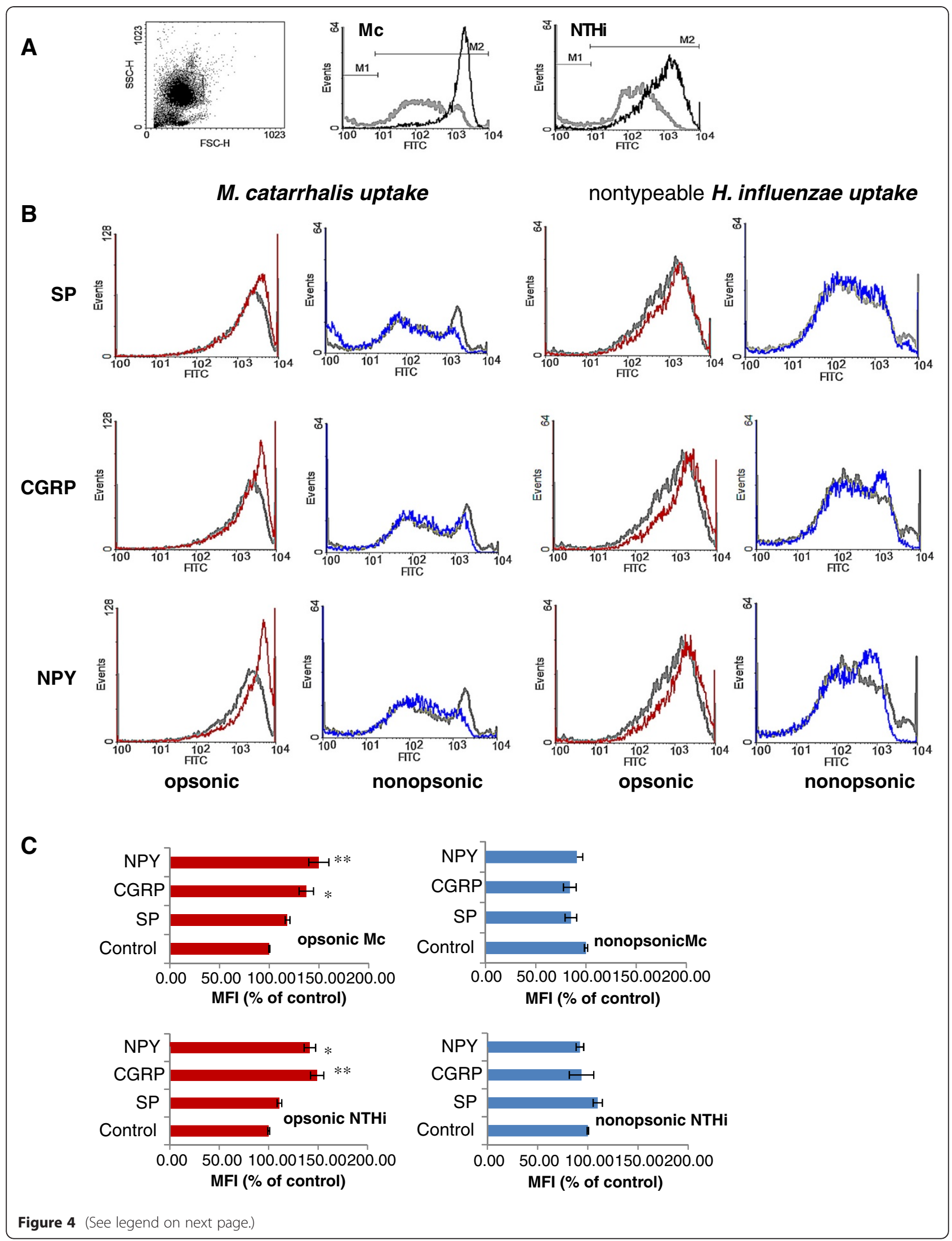




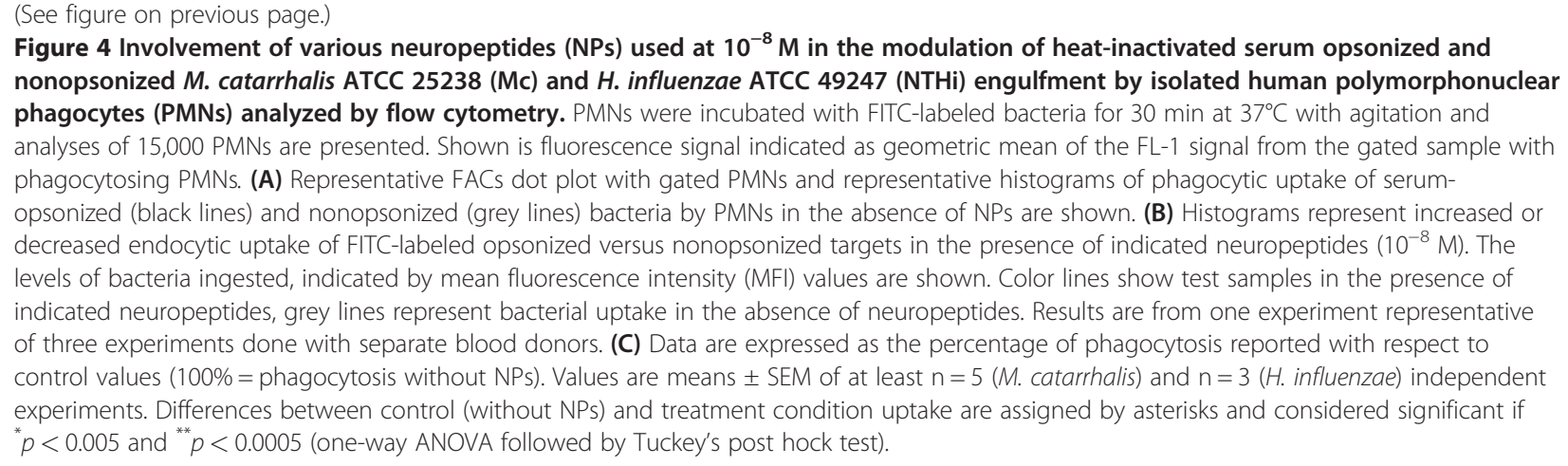

the kinetics of the lethal effect depends on individual peptide-membrane interactions.

Amounts of NPs regarded as physiological $\left(10^{-12}\right.$ to $\left.10^{-8} \mathrm{M}\right)$ imply that bactericidal activities of NPs defined in this study are of only pharmaceutical significance. Nevertheless, we cannot rule out that neuropeptide levels may be locally elevated in response to infection or other inflammatory condition. An example of such neuropeptide alteration may be the marked increase of SP expression in the airways, following respiratory syncytial virus infection [49]. Additionally, despite the fact that neuropeptides are released from nerve endings, they can also be synthesized in and released from the immune cells such as lymphocytes, monocytes/macrophages [17-19] as well as airway epithelial cells [50] or fibroblasts [51]. Therefore, locally high concentration of NPs, sufficient for bactericidal activity, is possible under certain inflammatory state in the respiratory tract.

Ten-fold lower concentration $(10 \mu \mathrm{M})$ of all NPs was not effective. Nevertheless, despite the lack of lethal activity, SOM being an exception, it altered the permeability barrier of model E. coli ML-35 mutant. Hypothetically, such an alteration could promote an interaction with final intracellular targets for a variety of extracellular molecules, including the neuropeptide itself [47]. In that case, the potential neuropeptide-mediated induction of the bacterial sensitization to other endogenic (defensins) or egzogenic (antibiotics) compounds could indirectly contribute to the local antimicrobial activity of the host or to the antimicrobial activity enhanced by chemiotherapeutics. The alliance between the cationic peptide magainin II and the betalactam antibiotics against Pseudomonas aeruginosa [52] may be an example of such synergism. However, the potential role of synergistic reactions between neuropeptides and others antimicrobials remains to be determined.

The direct antibacterial potential of substance $P$ against laboratory strains of $E$. coli, $P$. aeruginosa, $P$. vulgaris, E. faecalis, and $S$. aureus was firstly reported in 2002 using the microdilution broth method [21]. Conversely, in 2006, using radial diffusion assay, it was demonstrated a lack of the antibacterial effect of substance $\mathrm{P}$ and neuropeptide $\mathrm{Y}$ on laboratory strains of $S$. aureus and $P$. aeruginosa [22]. Recently, antimicrobial activities of various neuropeptides against a wide range of laboratory microorganisms $(S$. mutans, L. acidophilus, E. coli, E. faecalis, P. aeruginosa, C. albicans) typical for skin, oral cavity, respiratory tract and gastrointestinal tract has been reported [23]. These discrepancies may be the result of different susceptibilities of strains used in the above studies, as many human cationic peptides demonstrate a strain-selective activity against microorganisms [53]. Another reason may be the different detection limits of particular methods employed. For example, a radial diffusion assay showed the resistance of Porphyromonas gingivalis ATCC 49417 strain to $\beta$ defensins [53], whereas a microtiter method and a DNA binding dye demonstrated its sensitivity to the same antimicrobials [54]. It has been demonstrated that subtle

Table 3 Neuropeptide-mediated stimulation of fMLF-induced ROS generation by PMNs in luminol-dependent chemiluminescence

\begin{tabular}{|c|c|c|c|c|c|c|c|c|c|}
\hline \multirow[t]{3}{*}{ Stimulus } & \multicolumn{9}{|c|}{ ROS release [\% of control] } \\
\hline & \multicolumn{3}{|l|}{ SP } & \multicolumn{3}{|l|}{ NPY } & \multicolumn{3}{|l|}{ CGRP } \\
\hline & $10^{-8} \mathrm{M}$ & $10^{-10} \mathrm{M}$ & $10^{-12} \mathrm{M}$ & $10^{-8} M$ & $10^{-10} \mathrm{M}$ & $10^{-12} \mathrm{M}$ & $10^{-8} \mathrm{M}$ & $10^{-10} \mathrm{M}$ & $10^{-12} \mathrm{M}$ \\
\hline \multirow[t]{2}{*}{$\overline{f M L F}$} & $179.18^{a}$ & $160.36^{a}$ & $140.83^{\mathrm{a}}$ & 113.33 & $136.04^{\mathrm{a}}$ & $129.67^{c}$ & $266.41^{a}$ & $164.35^{\mathrm{a}}$ & $153.47^{b}$ \\
\hline & $(4.99)$ & $(3.80)$ & $(5.22)$ & $(6.64)$ & $(3.91)$ & $(3.26)$ & $(8.37)$ & $(13.47)$ & $(1.5)$ \\
\hline
\end{tabular}

Human PMNs $\left(10^{5}\right.$ cells/well) were incubated in the presence of $0.2 \mu \mathrm{M}$ of fMLF and three concentrations of each NPs and chemiluminescence was measured up to 30 min using Berthold Microlumat luminometer. Values are expressed as relative changes from controls (PMNs $+\mathrm{fMLF}$ ) and were calculated based on the maximal $\mathrm{CL}$ increase $\left(\mathrm{PH}_{\mathrm{CL}}\right)$. The presented results are means $\pm(\mathrm{SEM})$ of three independent experiments performed at least in triplicate. ${ }^{\mathrm{a}-\mathrm{c}}$ Significantly different from fMLF-stimulated ROS increase $\left({ }^{\mathrm{a}} p<0.0005 ;{ }^{\mathrm{b}} p<0.001 ;{ }^{\mathrm{c}} p<0.05\right)$ as determined by Tuckey's post hock test. 
changes in methods for testing cationic peptides bring about marked differences in their activity [48]. Our results seem to confirm that explanation, since, unlike the liquid broth time kill assay in which $100 \mu \mathrm{M}$ CGRP, NPY, and SP displayed killing activity against $\sim 2 \times 10^{6} \mathrm{CFU} / \mathrm{ml}$ of selected clinical isolates, such activity against the same bacterial load was not observed, when using a radial diffusion assay.

Using the data for the peptides analyzed in this paper and by other authors $[21,23]$ we assessed the relationships between direct antibacterial activities of these peptides and their physicochemical properties as well as the amino acid composition deduced from their sequences. The performed meta-analyses revealed statistically significant relationships between many analyzed parameters. These relationships did not always show consistent trends for all considered experiments and seemed to depend rather on the tested set of peptides than the studied bacterial species or strains. The nonuniversality of these tendencies and its dependence on peptide sets may indicate that a similar antimicrobial activity can be achieved by peptides with different characteristics or that variable degree of this activity is exerted by the same peptide due to various experimental conditions applied for different bacterial species tested (e.g. properties of their envelopes). It is also likely that the antibacterial activity of peptides results from a superposition of many physicochemical properties, whose contribution to and influence on this activity may be different in various antimicrobial peptides that fold into different structures. Therefore, some observed specificities of NPs may result from their potential ability to form other bonds which are specific in each particular peptidemembrane system. These bonds, such as for example hydrogen bonds, are likely to cause specific configurational and conformational modification of lipid bilayer and the membrane proteins, respectively. All mentioned above consequences of the bonds may change the antibacterial peptide capacity. Our observations confirm that peptide-membrane interactions are determined by a sensitive balance of electrostatic and hydrophobic interactions in which the universal, simple correlation between antimicrobial activity and specified structural feature of peptide is seldom demonstrated [45]. More extensive studies on the antimicrobial potency of many peptides under the same experimental conditions are necessary to evaluate more precisely the relationships between their activities and physicochemical features.

Polymorphonuclear neutrophils are the first leukocyte population that comes to the site of inflammation and play a key role in the eradication of invading pathogens. The next focus of our study was therefore on the immunomodulatory effects of NPs on important steps of granulocyte phagocytosis. We addressed the question whether granulocyte-mediated uptake and the generation of oxygen radicals during phagocytosis of $M$. catarrhalis and $H$. influenzae was modulated by NPY, SP, CGRP and if such modulation involved distinct types of pathogen recognition. As expected, precoating with serum immunoglobulins significantly enhanced the phagocytic uptake by PMNs and the ability of bacterial stimuli to release ROS from human PMNs. Next, we found that all the studied NPs accelerate the phagocytic uptake of both mucosal pathogens but only in the presence of specific opsonins, whereas the stimulatory effect of NPs was not observed in their absence. Thus, the effect of NPs seems to be additive with that produced by opsonized bacteria.

Unlike phagocytic uptake, the results of the NPs impact on bacteria-stimulated ROS response showed quite different modulatory effect. We reported that NPs stimulated the respiratory burst of PMNs in the absence of opsonins while reducing oxidative burst in response to serumtreated bacteria. Under the conditions of our assays, this effect appeared to be not restricted to M. catarrhalisinduced response, since response to NTHi was also diminished. The finding that NPs increase the uptake of opsonized bacteria without the intensifying the respiratory burst suggests that NPs may promote bacterial uptake without exacerbating oxidant release. It follows therefore that the NP-mediated amplification of bacteria-stimulated redox metabolism of PMNs, which is required for the generation of bactericidal oxygenating agents, may be attributed only to the initial phagocytic response against the studied bacteria, that do not involve antibody cooperation. In fact, cationic peptides, found to be critical for the interaction with endotoxin, could directly enhance ROS amplification by pathogen opsonization or by exerting synergistic effect together with endotoxin [55,56]. Additionally, the insensitivity of the opsonin-dependent ROS response to NPs may indicate that its origin is probably not connected to Ig-dependent signaling. These findings strengthen the observation of bimodal action of NPY [8] and probably other NPs. Furthermore, they suggest that depending on the different receptor interplay, an efficient pathogen uptake and their effective elimination may be provided. These results also suggest that the increase in NP-mediated bacterial uptake and the ROS formation in the response to bacterial stimuli are separate and distinguishable characteristics of PMNs.

Although demonstrating the modulation of phagocytic PMNs activity by NPY, SP, and CGRP, the receptors mediating these effects were not identified in our study. However, the expression of SP $\left(\mathrm{NK}_{1}, \mathrm{NK}_{2}, \mathrm{NK}_{3}\right)$ and NPY (Y1, Y2, Y4, Y5), membrane specific receptors on human PMNs, was previously confirmed by both molecular and pharmacological approach. Furthermore, it has been shown that SP and NPY had regulatory effect on human PMNs via the set of above-mentioned receptors 

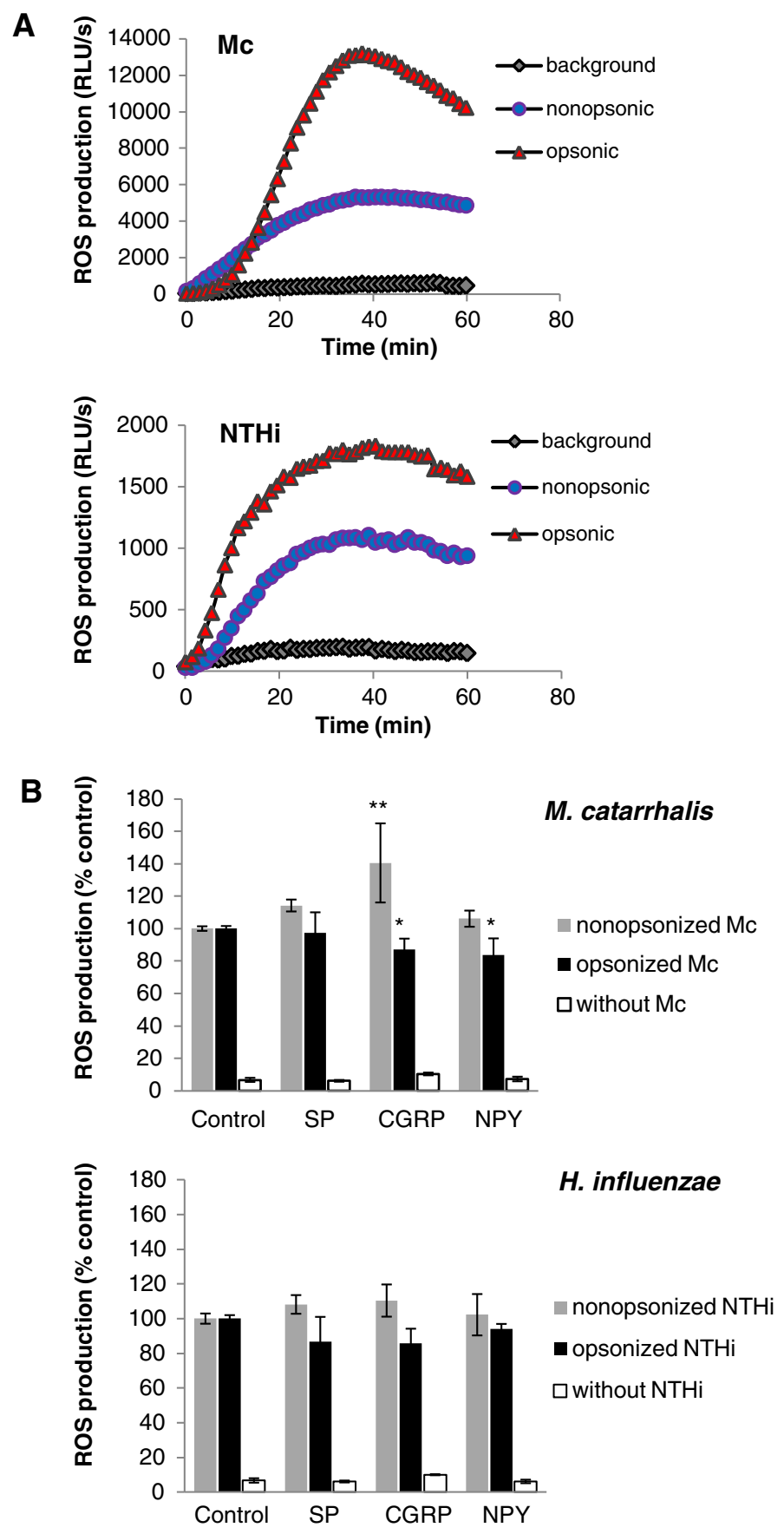

Figure 5 Influence of neuropeptides on ROS generation by human PMNs. Human PMNs (10 $/$ well) were added to $\sim 10^{7}$ CFU of nonopsonized or 10\% heat-inactivated serum-opsonized M. catarrhalis ATCC 25238 (Mc) or nontypeable H. influenzae ATCC 49247 (NTHi) or to wells without bacteria in the presence or absence of $10^{-8} \mathrm{M}$ of given neuropeptides and luminol-dependent chemiluminescence was measured up to 60 min using Berthold Microlumat luminometer. (A) Kinetics of ROS generation in human PMNs in response to bacterial stimulation in the absence of NPs. The results are expressed as mean relative light units/sec (RLU/s). The representative experiment performed in triplicate is shown (B) Histograms represent the $\mathrm{AUC}_{\mathrm{CL}}$ (mean $\pm \mathrm{SD}$ ) of at least 3 independent experiments done in triplicate from different donors. Results are expressed as a percentage of the PMN response stimulated only with bacteria. Asterisks indicate statistically significant differences calculated with reference to relevant controls if ${ }^{*} p \leq 0.05$ and ${ }^{* *} p<0.0005$ (one-way ANOVA followed by Duncan's post hock test). 
$[8,57]$. It is difficult to explain why the stimulatory phagocytic effect of NPs was exerted during the opsonindependent uptake as well as the opsonin-independent ROS response. The underlying mechanisms for these contradictory effects were not further explored in this study. At present, we can only speculate that the IgG-FcyR interaction favors signals triggered by NPs, whereas CEACAM3 (the opsonin-independent phagocytic receptor that functions specifically in the recognition and clearance of $M$. catarrhalis and nontypable $H$. influenzae by human granulocytes [58]) as well as other innate receptors such as TLR4, exert the opposite effect. Receptors often function cooperatively during microbial uptake and many parallel signaling pathways are simultaneously activated [59]. Furthermore, because signaling during phagocytosis may vary in response to signals from other receptors, it can modify the activation state of the phagocyte [60]. We postulate from this finding that even if a successful engulfment of mucosal pathogens by PMNs involves distinct types of pathogen recognition, the opsonin-dependent pathway seems to be the most relevant in view of the enhanced uptake elicited by neuropeptides. Our results are in partial agreement with the previous data on stimulatory action of NPY against E. coli, although it was tested only in opsonic conditions [8].

Unlike the confirmed presence of SP and NPY receptors on PMNs, the data from the literature do not support the presence of functional CGRP-specific receptors on mature granulocytes [61]. Thus, the fact that both critical phagocytic steps of PMNs, namely the engulfment and the ROS generation, were considerably intensified in the presence of CGRP was an unexpected finding. A lack of functional CGRP receptors on the surface of PMNs does not preclude the involvement of other mechanism of CGRP action such as non-specific receptor usage. It was demonstrated that CGRP may enhance phagocytosis as a result of the engagement of phagocytic mannose-receptors [46]. A direct activation of PMNs by CGRP has been additionally reported [62]. Further studies are necessary to find out what mechanisms underline the CGRP-mediated stimulation of PMN phagocytosis. Summing up, the contradictory action of NPs on $M$. catarrhalis and $H$. influenzae engulfment and ROS response by human PMNs seems to be determined both by the nature of pathogen recognition and by the physiological status of PMN donor. This type of bimodal effect has been reported for various neuropeptides as well as various concentrations of the same neuropeptide on phagocytosis, reactive oxygen production, phagocytic cell adherence and migration or cytokine release $[8,63]$.

In conclusion, we established a direct antibacterial action of CGRP, NPY, SP, and SOM against $M$. catarrhalis and nontypeable $H$. influenzae as well as (apart from
SOM) indirect antibacterial effect of the neuropeptides through immunomodulation of PMN phagocytosis. Therefore, CGRP, NPY, and SP, seem to be important molecules involved in innate host defense against $M$. catarrhalis and in part also against nontypeable $H$. influenzae. In higher concentrations they are bactericidal, whereas in lower, physiologically relevant doses, they show immunomodulating properties. The finding regarding the relevance of $10^{-8} \mathrm{M}$ and lower NPs doses may have. physiological or clinical implications. Substance P, NPY, and CGRP may induce chemotaxis of neutrophils, monocytes and macrophages $[64,65]$, therefore attract phagocytic cells to the site of infection. The NPY can modulate critical phagocytic function of PMNs including engulfment and ROS production [8]. Substance P may significantly induce an expression of cyclooxygenase-2, an activation of nuclear factor NF- $\mathrm{k} \beta$, and release of prostaglandin $\mathrm{PGE}_{2}$ from PMNs [57], as well as trigger mast cells priming and degranulation [66,67], all leading to an inflammatory response. In the context of adaptive immunity, the SP-mediated release of IgG1, IgG3, and IgG4 subclasses implicates its possible importance in antibodymediated responses during infection [68]. Furthermore, CGRP, NPY, SP, and SOM can also directly affect $\mathrm{T}$ cell functions, as they can modulate $\mathrm{T}$ cell migration [69] or induce secretion of cytokines such as IL-2, IFN- $\gamma$, IL4, and IL- 10 by Th1 and Th 2 cells in response to antigenic stimulation [3]. All these events may contribute to the local antimicrobial activity of neuropeptides in vivo.

It is noteworthy that low NP levels may act in concert with other inflammatory mediators. Such synerginistic response of low SP doses under stimulation with LPS has been shown to potentiate the neutrophil adherence to epithelial cells and cytokine release [70]. NPY and SP can also activate epithelial cells to produce other antimicrobials such as cathelicidins or $\beta$-defensins [2] whose bactericidal activities against $M$. catarrhalis and nontypeable $H$. influenzae have been documented [71]. Our observations expand on the previous findings for NPY, CGRP, SP, and are new in the case of SOM direct involvement in antibacterial innate immunity. They show also that neuropeptide-dependent modulation of phagocytosis of the respiratory pathogens under study is a bidirectional phenomenon. However, further research is needed to provide the insight into the particular mechanisms of NPs action and their real clinical significance in the microbial diseases caused by $M$. catarrhalis and H. influenzae.

\section{Conclusion}

The present results indicate that neuropeptides such as CGRP, NPY, and SP can effectively participate in the direct and indirect (immunomodulating) elimination of human-specific respiratory pathogens and seem to be 
important molecules involved in the innate host defense against $M$. catarrhalis and nontypeable $H$. influenzae.

\section{Abbreviations}

$A \cup C_{\mathrm{CL}}$ : area under chemiluminescence curve; $\mathrm{CL}$ : luminol-dependent chemiluminescence assay; CGRP: calcitonin gene related peptide; FITC: fluorescein isothiocyanate; fMLF: N-formyl-L-methionyl-L-leucyl-Lphenylalanine; Mc: Moraxella catarrhalis; MFI: mean fluorescence intensity; MIC: minimal inhibitory concentration; NP: neuropeptide; NPY: neuropeptide Y; NTHi: nontypeable Haemophilus influenzae; ONPG: o-nitrophenyl- $\beta$-Dgalactopyranosid; $\mathrm{PH}_{\mathrm{Cl}}$ : peak height of chemiluminescence curve; PMA: phorbol myristate acetate; PMNs: polymorphonuclear leukocytes; RLU: relative light unit; ROS: reactive oxygen species; SOM: somatostatin; SP: substance P.

\section{Competing interest}

The authors declare that there are no conflicts of interest.

\section{Authors' contributions}

DA conceived the study, conducted the majority of experimental work, performed statistical analyses, interpreted the data and wrote the manuscript. AJ conceived the study and helped to finalize the manuscript. PM performed analyses on relationships between activities of neuropeptides and their physicochemical characterization and co-wrote the manuscript. AS performed $\beta$-galactosidase assays and in part radial diffusion assays. JG provided expert advice with regards to membrane-peptide interaction. ZD-K identified clinical isolates and provided expert advice regarding antimicrobial assays. All authors read and approved the final manuscript.

\section{Acknowledgements}

The authors thank Dr Timothy D. Starner, Department of Pediatrics, Medicine University of lowa, lowa City, USA for sharing E. coli ML-35p strain, Judyta Nowak for her assistance with chemiluminescence assay, Conrad Firling and Marian Zamorski for their assistance to help in improving the English of this paper, and Dorota Dziadkowiec for helpful discussions. This work was supported by research grants of University of Wroclaw (1016/IGiM/2010) and Medical University of Wroclaw (ST470/AM/2010-2011).

\section{Author details}

'Department of Pathogen Biology and Immunology, Institute of Genetics and Microbiology, University of Wroclaw, Przybyszewskiego 63/77, 51-148 Wroclaw, Poland. ${ }^{2}$ Department and Clinics of Pediatrics, Immunology and Rheumatology of Developmental Age, Medical University of Wroclaw, Kasprowicza 64/66, 51-137 Wroclaw, Poland. ${ }^{3}$ Department of Genomics, Faculty of Biotechnology, University of Wroclaw, Przybyszewskiego 63/77, 51-148 Wroclaw, Poland. ${ }^{4}$ Depertment of Physico-Chemistry of Microorganisms, Institute of Genetics and Microbiology, University of Wroclaw, Przybyszewskiego 63/77, 51-148 Wroclaw, Poland.

Received: 21 October 2011 Accepted: 14 April 2012 Published: 2 May 2012

\section{References}

1. Sternberg EM: Neural regulation of innate immunity: a coordinated nonspecific host response to pathogens. Nat Rev Immunol 2006, 6:318-328.

2. Brogden KA, Guthmiller JM, Salzet M, Zasloff M: The nervous system and innate immunity: the neuropeptide connection. Nat Immunol 2005, 6:558-563.

3. Levite M: Neuropeptides by direct interaction with T cells induce cytokine secretion and break the commitment to a distinct $\mathrm{T}$ helper phenotype. PNAS 1998, 95:12544-12549.

4. Cuesta MC, Quintero L, Pons H, Suarez-Roca H: Substance P and calcitonin gene-related peptide increase IL-1 $\beta$, LL- 6 and TNF- $a$ secretion from human peripheral blood mononuclear cells. Neurochem Int 2002, 40:301-306.

5. Ding W, Stohl LL, Wagner JA, Granstein RD: Calcitonin gene-related peptide biases Langerhans cells toward Th2-type immunity. J Immunol 2008, 181:6020-6026.

6. Dunzendorfer S, Kaser A, Meierhofer C, Tilg H, Wiedermann CJ: Peripheral neuropeptides attract immature and arrest mature blood-derived dendritic cells. J Immunol 2001, 166:2167-2172.
7. Ahmed AA, Wahbi AH, Nordlin K: Neuropeptides modulate a murine monocyte/macrophage cell line capacity for phagocytosis and killing of Leishmania major parasites. Immunopharmacol Immnotoxicol 2001, 23:397-409.

8. Bedoui S, Kromer A, Gebhardt T, Jacobs R, Raber K, Dimitrijevic M, Heine J, von Hörsten S: Neuropeptide $Y$ receptor-specifically modulates human neutrophil function. J Neuroimmunol 2008, 195:88-95.

9. Delgado M, Ganea D: Anti-inflammatory neuropeptides: A new class of endogenous immunoregulatory agents. Brain Behavior and Immunity 2008, 22:1146-1151.

10. Elenkov IJ, Wilder RL, Chousos GP, Vizi ES: The sympathetic nerve - an integrative interface between two supersystems: the brain and the immune system. Pharmacol Rev 2000, 52:595-638.

11. Chanez P, Springall D, Vignola AM, Moradoghi-Hattvani A, Polak JM, Godard $P$, Bousquet J: Bronchial mucosal immunoreactivity of sensory neuropeptides in severe airway diseases. Am J Respir Crit Care Med 1998, 158:985-990.

12. Hellström S, Goldie P: Mechanisms of otitis media development. Involvement of neurogenic inflammation. Otolaryngol Clin North Am 1991, 24:829-834.

13. Hauser-Kronenberg C, Hacker GW, Muss W, Saria A, Albegger K: Autonomic and peptidergic innervations of human nasal mucosa. Acta Otolaryngol Stockh 1993, 113:387-393.

14. Figueroa JM, Mansilla E, Suburo AM: Innervation of nasal turbinate blood vessels in rhinitic and nonrhinitic children. Am J Respir Crit Care Med 1998, 157:1959-1966.

15. Basak S, Dikicioglu E, Turkutanit S, Sarierler M: Early and late effects of capsaicin pretreatment in otitis media with effusion. Otol Neurotol 2005, 26:344-350.

16. Belvisi MG: Overview of the innervations of the lung. Curr Opin Pharmacol 2002, 2:211-215.

17. Schwarz H, Vilinger PM, von Kempis J, Lotz M: Neuropeptide $Y$ is an inducible gene in the human immune system. J Neuroimmunol 1994, 51:53-61.

18. Ho W-Z, Lai J-P, Zhu X-H, Uvaydova M, Douglas SD: Human monocytes and macrophages express substance $P$ and neurokinin-1 receptor. J Immunol 1997, 159:5654-5660.

19. Wang H, Xing L, Li W, Hou L, Guo J, Wang X: Production and secretion of calcitonin gene-related peptide from human lymphocytes. J Neuroimmunol 2002, 130:155-162.

20. Brogden KA: Antimicrobial peptides: pore formers or metabolic inhibitors in bacteria? Nat Rev Microbiol 2005, 3:238-250.

21. Kowalska K, Carr DB, Lipkowski AW: Direct antimicrobial properties of substance P. Life Sci 2002, 71:747-750.

22. Hansen CJ, Burnell KK, Brogden KA: Antimicrobial activity of substance $P$ and neuropeptide $Y$ against laboratory strains of bacteria and oral microorganisms. J Neuroimmunol 2006, 177:215-218.

23. El Karim IA, Linden GJ, Orr DF, Lundy FT: Antimicrobial activity of neuropeptides against a range of microorganisms from skin, oral, respiratory and gastrointestinal tract sites. J Neuroimmunol 2008, 200:11-16.

24. De Vries SP, Bootsma HJ, Hays JP, Hermans PW: Molecular aspects of Moraxella catarrhalis pathogenesis. Microbiol Mol Biol Rev 2009, 73:389-406.

25. Nizet V, Colina KF, Almquist JR, Rubens CE, Smith AL: A virulent nonencapsulated Haemophilus influenzae. J Infect Dis 1996, 173:180-186.

26. Murphy TF, Bakaletz LO, Smeesters PR: Microbial interactions in the respiratory tract. Pediatr Infect Dis 2009, 28(10 suppl):S121-S126.

27. Murphy TF, Brauer AL, Grant BJ, Sethi S: Moraxella catarrhalis in chronic obstructive pulmonary disease: burden of disease and immune response. Am J Respir Crit Care Med 2005, 172:195-199.

28. Moghaddam SJ, Clement CG, De la Garza MM, Zou X, Travis EL, Young HW Evans CM, Tuvim MJ, Dickey BF: Haemophilus influenzae lysate induces aspects of the chronic obstructive pulmonary disease phenotype. Am J Respire Cell Mol Biol 2008, 38:629-638.

29. Mukundan D, Ecevit Z, Patel M, Mars CF, Gilsdorf JR: Pharyngeal colonization dynamics of Haemophilus influenzae and Haemophilus haemolyticus in healthy adult carriers. J Clin Microbiol 2007, 45:3207-3217.

30. Heiniger N, Spaniol V, Troller R, Vischer M, Aebi C: A reservoir of Moraxella catarrhalis in human pharyngeal lymphoid tissue. J Infect Dis 2007, 196:1080-1087.

31. Billal DS, Hotomi M, Suzumoto M, Yamauchi K, Kobayashi I, Fujihara K, Yamanaka N: Rapid identification of nontypeable and serotype $b$ 
Haemophilus influenzae from nasopharyngeal secretions by the multiplex PCR. Int J Pediatr Otorhinolaryngol 2007, 71:269-274.

32. Lehrer RI, Rosenman M, Harwiq SS, Jackson S, Eisenhauer P: Ultrasensitive assays for endogenous antimicrobial polypeptides. J Immunol Methods 1991, 137:167-173

33. Hoover DM, Boulegue C, Yang D, Oppenheim JJ, Tucker K, Lu W, Lubkowski $\mathrm{J}$ : The structure of human macrophage inflammatory protein-3a/CCL20. Linking antimicrobial and CC chemokine receptor-6-binding activities with human $\beta$-defensins. J Biol Chem 2002, 277:37647-37654.

34. Lehrer RJ, Barton A, Daher KA, Harwig SS, Ganz T, Selsted ME: Interaction of human defensins with Escherichia coli. Mechanism of bactericidal activity. J Clin Invest 1989, 84:553-561.

35. Starner TD, Barker CK, Jia HP, Kang Y, McCray PB Jr: CCL2O is an inducible product of human airway epithelia with innate immune properties. Am J Respir Cell Mol Biol 2002, 29:627-633.

36. Lamprou I, Mamali I, Dallas K, Fertakis V, Lampropoulou M, Marmaras VJ: Distinct signaling pathways promote phagocytosis of bacteria, latex beads and lipoppolysaccharide in medfly haemocytes. Immunology 2007, 121:314-327.

37. Tecle T, White MR, Gantz D, Crouch EC, Hartshorn KL: Human neutrophil defensins increase neutrophil uptake of influenza $A$ virus and bacteria and modify virus-induced respiratory burst responses. J Immunol 2007, 178:8046-8052.

38. Allen RC: Phagocytic leukocyte oxygenation activities and chemiluminescence: a kinetic approach to analysis. Methods Enzymol 1986, 133:449-493.

39. Gasteiger E, Hoogland C, Gattiker A, Duvaud S, Wilkins MR, Appel RD, Bairoch A: Protein Identification and Analysis Tools on the ExPASy Server. In The Proteomics Protocols Handbook. Volume 112. Edited by Walker JM. Humana Press. Full text - Copyright Humana Press; 2005:531-552.

40. Grantham R: Amino acid difference formula to help explain protein evolution. Science 1974, 185:862-864.

41. Kyte J, Doolittle RF: A simple method for displaying the hydropathic character of a protein. J Mol Biol 1982, 157:105-132.

42. Zhao G, London E: An amino acid "transmembrane tendency" scale that approaches the theoretical limit to accuracy for prediction of transmembrane helices: relationship to biological hydrophobicity. Protein Sci 2006, 15:1987-2006.

43. Deleage G, Roux B: An algorithm for protein secondary structure prediction based on class prediction. Protein Engineering 1987, 1:289-294.

44. Rice P, Longden I, Bleasby A: EMBOSS: The European Molecular Biology Open Software Suite. Trends Genet 2000, 16:276-277.

45. Dathe M, Wieprecht T: Structural features of helical antimicrobial peptides: their potential to modulate activity on model membranes and biological cells. Biochim Biophys Acta 1999, 1462:71-87.

46. Ichinose M, Sawada M: Enhancement of phagocytosis by calcitonin generelated peptide (CGRP) in cultured mouse peritoneal macrophages. Peptides 1996, 17:1405-1414.

47. Powers J-PS, Hancock REW: The relationship between peptide structure and antibacterial activity. Peptides 2003, 24:1681-1691.

48. Sánchez-Gómez S, Lamata M, Leiva J, Blondelle SE, Jerala R, Andrä J, Brandenburg K, Lohner K, Moriyón I, Martínez-de-Tejada G: Comparative analysis of selected methods for the assessment of antimicrobial and membrane-permeabilizing activity: a case study for lactoferricin derived peptides. BMC Microbiol 2008, 8:1-9.

49. Dakhama A, Park J-W, Taube Ch, El Gazzar M, Kodama T, Miyahara N, Takeda K, Kanehiro A, Balhorn A, Joetham A, Loader JE, Larsen G, Gelfand EW: Alteration of airway neuropeptide expression and development of airway hyperresponsiveness following respiratory syncytial virus infection. Am J Physiol Lung Cell Mol Physiol 2005, 288:L761-L770.

50. Chu HW, Kraft M, Krause JE, Rex MD, Martin RJ: Substance $P$ and its receptor neurokinin 1 expression in asthmatic airways. J Allergy Clin Immunol 2000, 106:713-722.

51. Killough SA, Lundy FT, Irwin CR: Substance P expression by human dental pulp fibroblasts: a potential role in neurogenic inflammation. J Endod 2009, 35:73-77.

52. Giacometti A, Cirioni O, Barchiesi F, Fortuna M, Scalise G: In-vitro activity of cationic peptides alone and in combination with clinically used antimicrobial agents against Pseudomonas aeruginosa. J Antimicrob Chemother 1999, 44:641-645.
53. Joly S, Maze C, McCray PB, Guthmiller JM: Human $\beta$-defensins 2 and 3 demonstrate strain-selective activity against oral microorganisms. J Clin Microbiol 2004, 42:1024-1029

54. Schelburne CE, Coulter WA, Olguin D, Lantz MS, Lopatin DE: Induction of $\beta$-defensin resistance in the oral anaerobe Porphyromonas gingivalis. Antimicrob Agents Chemother 2005, 49:183-187.

55. lovine NM, Elsbach P, Weiss J: An opsonic function of the neutrophil bactericidal/permeability increasing protein depends on both its $\mathrm{N}$ - and C-terminal domains. Proc Natl Acad Sci 1997, 94:10973-10978.

56. Zughaier SM, Shafer WM, Stephens DS: Antimicrobial peptides and endotoxin inhibit cytokine and nitric oxide release but amplify respiratory burst response in human and murine macrophages. Cell Microbiol 2005, 7:1251-1262.

57. Gallicchio M, Benetti E, Rosa AC, Fantozzi R: Tachykinin receptor modulation of cyclooxygenase-2 expression in human polymorphonuclear leucocytes. British J Pharmacol 2009, 156:486-496.

58. Schmitter T, Agerer F, Peterson L, Munzner P, Hauck CR: Granulocyte CEACAM3 is a phagocytic receptor of the innate immune system that mediates recognition and elimination of human-specific pathogens. J Exp Med 2004, 199:35-46.

59. Underhill DM, Ozinsky A: Phagocytosis of microbes: complexity in action. Ann Rev Immunol 2002, 20:825-852

60. Garcia-Garcia E, Rosales C: Signal transduction during Fc receptor-mediated phagocytosis. J Leuk Biol 2002, 72:1092-1108,

61. Harzenetter MD, Keller U, Beer S, Riedl C, Peschel Ch, Holzmann B: Regulation and function of the CGRP receptor complex in human granulopoiesis. Exp Hematol 2002, 30:306-312.

62. Richter J, Andersson R, Edvinsson L, Gullberg U: Calcitonin gene-related peptide (CGRP) activates human neutrophils - inhibition by chemotactic peptide antagonist BOC-MLP. Immunology 1992, 77:416-421.

63. Ganea D, Delgado M: Neuropeptides as modulators of macrophage functions. Regulations of cytokine production and antigen presentation by VIP and PACAP. Arch Immun Ther Exp 2001, 49:101-110.

64. Kaneider NC, Egger P, Djanani AM, Wiedermann ChJ: Leukocyte motility in response to neuropeptides is heperan sulfate proteoglycan dependent. Peptides 2003, 24:695-700.

65. Medina S, Del Rio M, Hernanz A, De la Fuente M: The NPY effects on murine leukocyte adherence and chemotaxis change with age. Adherent cell implication. Regul Pept 2000, 95:35-45.

66. Janiszewski J, Bienenstock J, Blennerhassett MG: Picomolar doses of substance $P$ trigger electrical responses in mast cells without degranulation. Am J Physiol Cell Physiol 1994, 267:138-145.

67. Bedoui S, Kawamura N, Straub RH, Pabst R, Yamamura T, von Horsten S: Relevance of neuropeptide $Y$ fo the neuroimmune crosstalk. J Neuroimmunol 2003, 134:1-11

68. Braun A, Wiebe P, Pfeufer A, Geßner R, Renz H: Different modulation of human immunoglobulin isotype production by the neuropeptides substance P, NKA, and NKB. J Neuroimmunol 1999, 97:43-50.

69. Levite M, Cahalon L, Herskoviz R, Steinman L, Lider O: Neuropeptides, via specific receptors, regulate $\mathrm{T}$ cell adhesion to fibronectin. J Immunol 1998, 160:993-1000

70. Kuo H-P, Lin H-Ch, Hwang K-H, Wang Ch-H LuL-Ch: Lipopolysaccharide enhances substance P-mediated neutrophil adherence to epithelial cells and cytokine release. Am J Respir Crit Care Med 2000, 162:1891-1897.

71. Lee H-Y, Andalibi A, Webster P, Moon S-K, Teufert K, Kang S-H, Li J-D, Nagura M, Ganz T, Lim DJ: Antimicrobial activity of innate immune molecules against Streptococcus pneumonia, Moraxella catarrhalis and nontypeable Haemophilus influenzae. BMC Infect Dis 2004, 4:1-12.

\section{doi:10.1186/1471-2172-13-24}

Cite this article as: Augustyniak et al: Innate immune properties of selected human neuropeptides against Moraxella catarrhalis and nontypeable Haemophilus influenzae. BMC Immunology 2012 13:24 